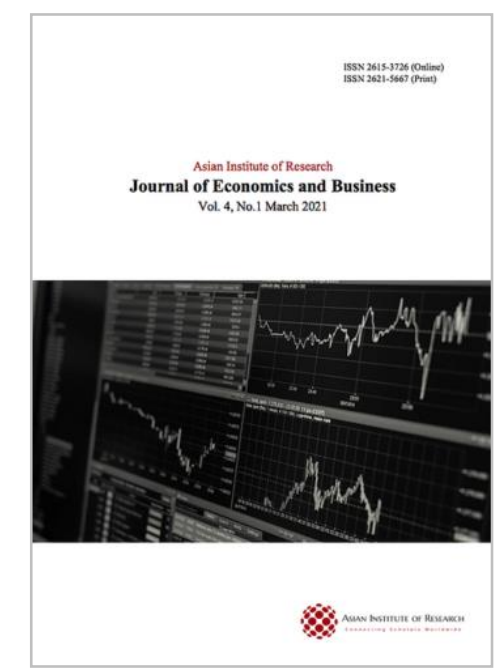

\title{
Journal of Economics
} and Business

Sanginabadi, Bahram. (2021), Oil and Mortality. In: Journal of Economics and Business, Vol.4, No.1, 272-293.

ISSN 2615-3726

DOI: 10.31014/aior.1992.04.01.337

The online version of this article can be found at: https://www.asianinstituteofresearch.org/

Published by:

The Asian Institute of Research

The Journal of Economics and Business is an Open Access publication. It may be read, copied, and distributed free of charge according to the conditions of the Creative Commons Attribution 4.0 International license.

The Asian Institute of Research Journal of Economics and Business is a peer-reviewed International Journal. The journal covers scholarly articles in the fields of Economics and Business, which includes, but not limited to, Business Economics (Micro and Macro), Finance, Management, Marketing, Business Law, Entrepreneurship, Behavioral and Health Economics, Government Taxation and Regulations, Financial Markets, International Economics, Investment, and Economic Development. As the journal is Open Access, it ensures high visibility and the increase of citations for all research articles published. The Journal of Economics and Business aims to facilitate scholarly work on recent theoretical and practical aspects of Economics and Business. 


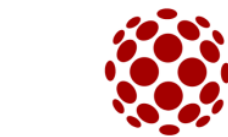

ASIAN INSTITUTE OF RESEARCH

connecting Scholars Worldwide
The Asian Institute of Research

Journal of Economics and Business

Vol.4, No.1, 2021: 272-293

ISSN 2615-3726

Copyright (C) The Author(s). All Rights Reserved

DOI: 10.31014/aior.1992.04.01.337

\title{
Oil and Mortality
}

\author{
Bahram Sanginabadi ${ }^{1}$
}

${ }^{1}$ Economics Department, University of Hawaii at Manoa. Email: bahram@ hawaii.edu

\begin{abstract}
This paper investigates the impacts of a large and exogenous oil price shock in December 1973 on mortality rates of the major oil producer nations of the Middle East and North Africa. We use longitudinal data from 1960 to 2014 and we apply the difference-in-differences approach to investigate the main question of the research. Our findings show that the oil price shock did not lead to higher GDP per capita, but it did lead to lower mortality. These findings are puzzling. A possible explanation is that the oil price shock allowed for higher spending on publicly funded health care. We find a positive impact of the oil price increase on the number of hospital beds which perhaps suggests that higher oil revenues increased spending on public health and that possibly decreased mortality.
\end{abstract}

Keywords: Oil Price Shock, Oil Revenue, Mortality

\section{Introduction}

An irony of our world is that the countries that are blessed with an easy income from natural resources are not usually blessed with higher welfare and prosperity. Would the people of resource-rich nations be healthier and live longer if they did not have their natural resources? In this study, applying an exogenous oil price shock in 1973 we attempt to shed light on the impacts of oil revenues on the mortality rates of major oil producer nations. The story goes back to the attempts of the Shah ${ }^{1}$ of Iran to increase the price of oil in the 1970s. Iran was a major producer of oil in those days. Hence, it possessed a significant amount of power in OPEC. The Shah's attempts to increase oil prices go back to 1971 which he successfully increased the oil price from $\$ 1.64$ to $\$ 4.1$ in three years. However, the real shock came in 1973 when the prices skyrocketed. In December 1973, the Shah forced OPEC $^{2}$ members to increase the price of crude oil by more than three hundred percent. The global price of crude oil which was \$4.1 in December 1973 increased to \$13.0 in January 1974. The documents, including a partially declassified CIA report entitled, Shah of Iran Culprit in High Oil Prices, show that the Shah, was the key person that can be blamed for the oil price shock of 1973-1974. Even though the OPEC members should agree on the oil price policies, the other OPEC members were not happy with the Iran's attempt for increasing the oil price. Saudi Arabia, another major oil producer and powerful member of OPEC tried to stop Iran from raising the prices. The Shah, who thought the oil reservoirs of Iran would be depleted before the year 2000, tried to industrialize Iran as fast as possible to eradicate poverty. The Shah of Iran dreamed about bringing back the great

\footnotetext{
${ }^{1}$ Mohammad Reza Shah Pahlavi, King of Iran from 1941 until 1979.

${ }^{2}$ The Organization of the Petroleum Exporting Countries (OPEC) is an organization of some major oil suppliers that acts like a cartel to control the global price of oil
} 
Persian civilization ${ }^{3}$, and needed money to fund his dream. The following quote by Garavini, G. (2011) explains why the Shah was interested in increasing the prices:

\section{"During period of high production, Shah hopes to see Iran transformed into an industrial power comparable with France or West Germany. Needs high prices and high production rates to see Iran make such great strides during lifetime. Therefore, his insistence on huge price hikes and refusal to cut back production" (p. 481).}

Painter (2014) argues that in the late 1960s, the British wanted to withdraw their military forces from the Persian Gulf in the south of Iran. Therefore, the United States, busy with the Vietnam war, turned to Iran to serve as the guardian of the Persian Gulf. The Shah of Iran eagerly accepted to be the guardian of the Persian Gulf because he was trying to establish the power of ancient Persia once again. In 1972, the Nixon administration agreed to sell any military equipment except nuclear weapons to Iran. Between 1970 and 1978, Iran purchased over 20 billion dollars worth of weapons and other military equipment from the US. Painter maintains that "higher [oil] prices allowed Iran to increase its military spending and replace Great Britain as the "guardian of the gulf." (p. 197).

Why it matters to study the impacts of oil revenues on mortality? One reason is that the plausible impacts of oil revenues on mortality are neglected in the literature. A large literature studies the impacts of income from natural resources on economic growth. Although this literature has tackled crucial questions, the problem is that economic growth solely is an imperfect proxy for welfare. In a highly unequal society that a small percentage of the population controls most of the wealth of the nation, economic growth could be noticeably high. Unlike economic growth, mortality could be highly informative about the well-being of the whole population. Oil revenues could bring large amounts of income to a country. If oil income is invested in building and improving hospitals and in other health-relevant factors, even in the short term, it can have a significant impact on reducing child mortality. The public sector often plays a highly crucial role in health care. Perhaps higher oil revenues for the public sector facilitate more spending on health care. Another reason is that it is intrinsically valuable to understand the factors that save human life and decrease mortality.

Preston ${ }^{4}$ (2007) might be the most influential study that investigates the connection between income and mortality. He argues, besides an improvement in health services such as an increase in quality and quantity of the hospitals and clinics, a higher level of wealth helps a society to afford more nutritious and healthier food, leisure, education, etc. that might indirectly affect mortality rates. He finds an association between national income per head and life expectancy for the 1900s, 1930s, and 1960s. His study has other important findings as well. First, income per capita has a non-linear, positive effect on life expectancy. The effect attenuates as countries become richer. Second, the relationship has shifted upward over time. Third, "Factors exogenous to a nation's level of income per head have had a major effect on mortality trends in more developed as well as in less developed countries" (p. 489). He explains that income levels per se account for 10 to 20 percent of growth in life expectancy. Factors exogenous to a country's current level of income account for 75 to 90 percent. He argues that the association between national income and life expectancy is indirect and if higher national income goes to public health, nutrition, education, etc. then it can decrease mortality and improve life expectancy:

There is no reason to expect a direct influence of national income per head on mortality; it measures simply the rate of entry of new goods and services into the household and business sectors. Its influence is indirect; a higher income implies and facilitates, though it does not necessarily entail, larger real consumption of items affecting health, such as food, housing, medical and public health services, education, leisure, health-related research and,

\footnotetext{
${ }^{3}$ He even published a book in 1978 entitled Toward the Great Civilization

${ }^{4}$ Preston published the first version of his paper in 1975
} 
on the negative side, automobiles, cigarettes, animal fats and physical inertia (p. 484.)

There has been debates on the relative importance of the mentioned factors above. While Preston (2007) and Deaton (2006) emphasize the roles of public health measures, Fogel (2004) puts more weight on the of impacts of rising income on nutrition. In addition to Preston (2007), Kitagawa and Philip (1973), Cutler et al. (2006), Cristia (2007), Mackenbach et al. (2008), Duggan (2008); Braveman et al. (2010), Waldron (2013), Chetty et al. (2016) have found that a greater wealth does lead to a lower mortality and higher life expectancy. However, not every study finds a significant effect of income on mortality reduction. At least two studies including Stolnitz (1965) and Demeny (1965) find no significant relationship between income per capita and mortality.

The impacts of oil price shocks on different aspects of an economy have been widely discussed in the literature (see e.g. Park and Ratti, 2008; Jimenez-Rodriguez, 2008; Farzanegan and Markwardt, 2009; Iwayemi and Fowowe, 2011; Aydın and Acar, 2011; Scholtens and Yurtsever, 2012; Cunado and de Gracia, 2014; Gao et al., 2014; Kang et al., 2014; Zhang and Qu, 2015; Tsai, 2015; Cunado et al., 2015; Ju et al., 2016; Zhang and Tu, 2016; Nusair, 2016; Zhao, 2016; Kim et al., 2017; Cross and Nguyen, 2017; Lee et al., 2017; Karnizova and Reza, 2018; Moshiri and Moghaddam, 2018; Nasir et al., 2018; Ioannidis and Ka, 2018; Oladosu et al., 2018; Lorusso and Pieroni, 2018; Tchatoka et al., 2018; Herrera et al., 2019; Lee and Lee, 2019; Nusair and Olson, 2019; Grigoli, et al., 2019; Bergmann, 2019). However, the mentioned studies are different from our paper because what they consider as oil price shocks is not a same concept as what we refer to as the 1973 oil price shock. The oil price shocks in the mentioned studies mostly refer to oil price volatilities or oil price uncertainties. However, in our paper we focus on the oil price increase in 1973 as an exogenous variation in oil price to study the impacts of oil revenues on mortality in oil producing nations. In addition, the impacts of oil price change or oil price shocks on welfare and economies of the oil producing nations has not received attention in the literature and most of the studies focus on the economies of the large oil consumers such as the United States and China.

Note that, as the results of this paper confirms, the oil price shock in 1973 had a negative and significant impact on mortality rate (i.e. decreased mortality) and at the same time led to a lower rate of per capita economic growth. The reasons why oil revenues might negatively affect economic growth has been discussed in the Resource Curse literature. The Resource Curse literature mostly argues that natural resource discoveries decrease economic growth and income per capita (see e.g. Sachs and Warner, 1995; Velasco, 1997; Gylfason et al., 1999; Tornell and Lane, 1999; Leite and Weidmann, 1999; Ross, 2001; Papyrakis and Gerlagh, 2007; Caselli and Cunningham, 2009; Brollo et al., 2010; Vicente, 2010; Van der Ploeg, 2011; Sala-i Martin and Subramanian, 2013). Resource curse studies argue that due to reasons such as Dutch Disease, corruption, weakening the institutions, etc. income from natural resources has an adverse impact on economic growth. For example, Papyrakis and Gerlagh (2007) argue that abundance of natural resources increases corruption and decreases R\&D expenditure, openness, schooling, and investment. Also, they maintain that in more volatile economies with poor financial systems, high corruption, lack of rule of law, and political issues the mentioned problems could be more severe. Also, other studies show natural resource windfalls might decrease investment and openness and have negative effects on schooling and economic growth (Papyrakis and Gerlagh, 2007).

One explanation for resource curse relates to change in incentives or behavior of the politicians. Caselli and Cunningham (2009) argue that income from natural resources can alter the incentives of the leaders and make them act in an opposite direction of well-being of their societies. Also, Velasco (1997) and Tornell and Lane (1999) maintain that a windfall of natural resources can have adverse effects on economies through political processes such as increased in rent-seeking. In addition, other studies of the resource curse literature emphasize an increase in corruption and a decrease in the quality of the politicians because of natural resource abundance (Brollo et al. 2010; Vicente 2010).

Another explanation for a negative impact of natural resource discoveries on economic growth is "Dutch Disease" which argues that the export of natural resources tends to increase exchange rates and hence diminishes 
the competitiveness of industrial exports (see e.g. Corden 1982; Corden and Neary,1984; Sachs and Warner, 1995; Gylfason et al., 1999; Van der Ploeg, 2011; Sala-i Martin and Subramanian, 2013).

In this paper we find negative impacts of the oil price shock of 1973 on GDP per capita as well as on mortality. Also, we find positive impacts of the oil price shock on hospital beds. Therefore, it seems that spending on public health has been increased after increase in price of oil. Because health sector is considered as a services sector Dutch Disease can provide one explanation for our results. Dutch Disease is hypothesized by Corden (1982) and Corden and Neary (1984). Dutch Disease hypothesizes that an exogenous shock in oil price increases the real exchange rate which results in decline in production of the agriculture and manufacturing sectors and increases the production of the services sector.

In Dutch Disease hypothesis the whole economy is divided to the sectors that produce tradable and non-tradable outputs. The tradable sectors include booming sector (oil) and lagging sector (agriculture and manufacturing). The non-tradable sector only includes services sector. The tradable sector is subject to global competition and the price of the outputs of the tradable sector (oil, manufacturing, and agriculture) are determined abroad by the global supply and demand functions. However, the price of the outputs of non-tradable sector (services) is not subject to global competition.

Corden and Neary (1984), differentiate a resource movement effect from a spending effect. The resource movement effect occurs in a condition that the supply of oil is not perfectly inelastic and an increase in global price of oil shifts up the demand for capital and labor in the oil (booming) sector. This will lead to larger return to capital and higher wages in the booming sector. In a condition that production factors are mobile this will cause a shift of capital and labor from services and lagging sectors (i.e. agriculture and manufacturing) to the booming sector (i.e. the oil sector)). The employment and output in the booming sector increase, while employment and output in lagging and services sectors decline. Decline in output of the lagging sectors is referred to as "direct de-industrialization." The price of lagging sector outputs is determined abroad and therefore remains unchanged. Fall in the production of services causes excess demand and hence a rise in the price of services. Therefore, the price of non-tradable products relative to the price of tradable products increases which leads to an increase in real exchange rate.

Usually the resource movement effect does not happen because the number of workers in the booming sector is low comparing to the whole economy. Nevertheless, the spending effect is likely to occur. The spending effect takes place because a raise in oil prices increases profits and wages in the oil sector which improves the aggregate demand in the whole economy. This does not affect the prices of manufacturing goods and oil since their prices are determined abroad by the global supply and demand functions, but prices of services increase. This again results in an increase in real exchange rate. The increase in price of services occurs because the rise in aggregate demand in the whole economy transfers to the services sector as well. If labor is mobile between the tradable and services sectors, an increase in the demand for services will lead to an upward shift in the supply of services. Also demand for labor and therefore wages in the services sector increase.

This will encourage workers to move from the tradable sector (i.e. oil and manufacturing) to the services sector and pushes the tradable sectors to increase their wages. However, they cannot compete and their profits fall. The resulting drop in employment and outputs of booming and lagging sectors is referred to as "indirect deindustrialization." by Corden and Neary (1984).

Combining the two effects, the Dutch Disease hypothesis generates some important predictions. One, there is an unambiguous decrease in production and employment in the manufacturing sector. Second, because the resource movement effect and the spending effect pull in opposite ways the overall effect on employment and production of the services and oil sectors is ambiguous. Nevertheless, if the oil sector employs a low ratio of workers of the whole economy, then the spending effect dominates the resource movement effect. This leads to increase in output and employment of services sector. In practice it has been shown that the spending effect dominates the resource movement effect (Oomes and Kalcheva, 2007; Hasanov, 2013). 
The mechanisms and the literatures discussed previously in this section provide some insights about the plausible impacts of the oil price shock of 1973 on mortality, and economic growth of the oil producer countries. To the best of our knowledge a similar study has not been done before. Therefore, this empirical study attempts to fill this gap in the literature. For reasons that are discussed in the Empirical Design section of the paper, difference-in-differences fixed effect models are applied to investigate the main question of the research.

The key findings of this research can be summarized as follow:

a. The oil price increase of 1973 decreased mortality rates including infant mortality rate, mortality under age 5 , adult female mortality rate, and adult male mortality rate in the oil producing nations of the Middle East and North Africa.

b. Another impact of the oil price shock is that it decreased GDP per capita. This result confirms the findings of the resource curse literature.

c. Yet another finding is the positive impact of the oil price shock on the number of hospital beds. This finding suggests that the oil producing nations improved their investments in health care after the windfall of oil revenue from the oil price shock.

In the discussion section we argue that the results of this paper could be perfectly be explained by Dutch Disease hypothesis. Yet, another explanation why hospital beds and mortality rates have improved despite the negative impact of the oil price shock on economic growth relates to the behavior and incentives of the politicians. Due to failure of the politicians in preventing resource curse they might try to invest on visible projects to people that may improve their popularity. Investing in health care such as building hospitals are visible to citizens and therefore might help the politicians to stay in power longer.

The rest of this paper is organized as follow. Section 2 outlines the empirical design of the research. Section 3 explains the Data and treatment assignment. Section 4 provides the results and section 5 presents the conclusion of the study.

\section{Empirical design}

Since the price shock was managed by the Iranian king, the increase in oil prices could be an endogenous variable for the Iranian economy. Nevertheless, it's unlikely that the price shock in 1973 was an endogenous variable for the economy of other oil producer nations. The oil price increased based on the decision of a person outside their country without them having a significant impact on the process. Hence the oil price shock of 19731974 is an exogenous variable for other nations, if not for Iran, and in this paper, we apply that to study the impacts of oil revenues on mortality in oil producing nations. The CIA report suggests that perhaps Venezuela was a supporter of Shah's decision. For this reason and other reasons that will be discussed later in the paper, Venezuela is not included in this paper. Hence, there is no concern about possible endogeneity of oil price increase in Venezuela's economy.

In this paper difference-in-differences (DID) approach has been applied to investigate the impacts of the oil price shock in 1973 on mortality rates. Also, we apply the same approach to estimate the impact of the oil shock on economic growth and hospital beds. Difference-in-differences (DID) approach estimates the impact of an event on an outcome variable by comparing the average change in the outcome variable for the treatment unit and the average change for the control group over time. We apply this approach because it provides a nice framework to investigate the impact of an event (an increase in oil price) on an outcome variable (mortality, for example). Card and Krueger (1994) might be the most famous study that used the difference-in-differences approach. They investigated the impacts of an increase in minimum wages (an event) on employment (an outcome variable) at fast food industry in New Jersey and Pennsylvania.

Before applying DID, we divide the countries in two groups. One is the treatment group and the other is the control group. A treatment unit, which is a country in the treatment group, is one of major oil producer nations. And the control countries are nations that do not produce oil in the same region (i.e. the Middle East and North Africa) with the treated countries. 
We apply the following model to estimate the average effect of the treatment on the outcome variables:

$Y_{c t}=\beta_{1}+\beta_{2}$ Post $_{t}+\beta_{3}$ Treat $_{c}+\beta_{4}$ Treat $_{c} *$ Post $_{t}+\alpha_{c}+\gamma_{t}+\epsilon_{c t}$

where $\mathrm{Y}_{c t}$ is the outcome variable in country $\mathrm{c}$ and year t. Post $t_{t}$ is an indicator which takes value one if $\mathrm{t}>\mathrm{T}_{0}$ where $\mathrm{T}_{0}$ is the event year (i.e. 1973). Post $t_{t}$ is zero for the years before the event. Treat $_{c}$ is an indicator that takes a value one if a country is treated (i.e. it is an oil-producing country). Treat $_{c}$ takes a value zero if a country is not treated (i.e. it is not an oil-producing country and it is one of the countries in the control group). $\alpha_{c}$ is country fixed effect. $\gamma_{t}$ is year fixed effect dummies for year $t$. This variable controls for the common shocks experienced across the region.

A key assumption of the difference-in-differences model is the common trend assumption. In fact, the identification in the difference-in-differences models relies on the common trends (parallel trends) assumption that requires the dependent variable for the treatment unit and the control group have the same trends. If the two groups have the same trend, then the differences should be due to the treatment.

The common trend assumption is not easy to verify. However, one can show that the outcome variable in the control and treatment groups are parallel before the treatment. Even if the pretreatment trends are parallel, changing policies and conditions after the treatment could affect the results. In this paper, the outcome variable which is $\mathrm{Y}_{c t}$ should be parallel for the treated countries and control group before the treatment. During the post treatment period, based on the mentioned assumption, if there was not a treatment, the outcome variable should be parallel in the treated and the control units. To meet the mentioned assumption, we limit this research to the Middle Eastern and North African countries. Some sub-Saharan African countries such as Nigeria are among major oil producers, but experienced high death rates in 1980s and 1990s because of reasons unrelated to oil revenues. Thus, for them the parallel trend assumption does not hold and they are not included in the analysis. In addition, Venezuela is one of top oil producing counties in Latin America, but again because the parallel trend assumption was not satisfied it is not included in the paper. Including the industrial European countries such as Norway which is among major oil producer nations violates the same assumption. The reason is that timing, pace, and level of industrialization among European countries that would create a control group for Norway significantly vary which makes it difficult to capture the impacts of oil revenues on mortality in Norway relative to its potential counterfactual. In other words, since the European nations have begun to industrialize not at the same time and same level, $\beta_{4}$ in equation 1 might get affected by timing and pace of industrialization of the treated and control countries and fail to show an unbiased impact of the oil price shock on mortality.

\section{Data and treatment assignment}

The source of oil production data is International Petroleum Encyclopedia. The source of GDP per capita is Maddison Project Database (MPD). Also, the global oil prices are taken from The World Bank Commodity Price Data. The source of the rest of the data is the World Bank.

The oil-producing countries that are considered as treated countries in this paper include Algeria, Bahrain, Iran, Iraq, Kuwait, Libya, Oman, Qatar, Saudi Arabia, Syria, Yemen, and United Arab Emirates. Also, the control group which are some other countries in the Middle East and North Africa (i.e. same region as the treated group) include Djibouti, Israel, Jordan, Lebanon, Morocco, Tunisia, Turkey. Because of possibility of endogeneity of the oil shock for the Iranian economy in some of the regressions Iran is excluded.

Figure 1 and shows the global price of oil from 1960 to 2005. The oil price shock in 1973 is charted using a dashed red line. Until the 1970s the price of oil was low for decades. As can be seen in Figure 1 from 1960 to 1970 the price of oil actually decreased a few cents each year. The oil price which was 1.63 U.S. dollars in 1960, 
over a decade, decreased to 1.21 U.S. dollars in 1970. However, after the Shah's pressure on the Seven Sisters 5 , an oligopoly that dominated the oil reserves and controlled the price of oil for decades, the price started increasing in the 1970s. In 1970 the Shah of Iran threatened the Seven Sisters that if they didn't consider the wish of the OPEC members in production/price negotiations, the OPEC members would change their policy and they would decide about oil prices themselves. After this event the Seven Sisters agreed to increase the price of oil to adjust for inflation of both producer and consumer countries. Hence the global price of oil increased from 1.21 U.S. dollars in December 1970 to 1.64 U.S. dollars in January 1971. Again, in July of 1971 the price of oil increased by 10 cents from 1.64 U.S. dollars to 1.74 U.S. dollars.

Every 6 months, from middle of 1971 until May 1973, the price of oil increased by 10 cents. However, in July 1973 it increased by 35 cents from 2.35 to 2.7 U.S. dollars. In October of the same year the price increased from 2.7 to 4.1 U.S. dollars.

However, comparing to price shock of December 1973-Jannuary 1974, the price increase of October 1973 is relatively moderate. In December 1973, the OPEC members had a meeting in Isfahan, Iran. Jamshid Amouzegar was Iran's representative in the meeting. He was asked by the Shah to use Iran's power in OPEC for a significant increase in oil price. However, even before the OPEC meeting was finished, the Shah of Iran announced that oil price has been raised in the OPEC meeting. The new global price of oil in January 1974 was \$13.0 U.S. dollars.

Note, that the price of oil increased again in 1979, but after a few years it came down and for over two decades stayed almost at the same level that it was in 1974. Again, Iran had a big role in price increase of 1979. In February 1979 Islamic Revolution happened in Iran and Shah lost his power. For a few years prior to 1979, Iran was one of the largest oil producers on Earth. However, over the same period, demonstrations against Shah were on rise. In 1978 and 1979 the workers of oil industry in Iran joined the demonstrators and stopped going to work. Therefore, the oil industry in Iran stopped functioning and oil production decreased significantly which was followed by an increase in oil price.

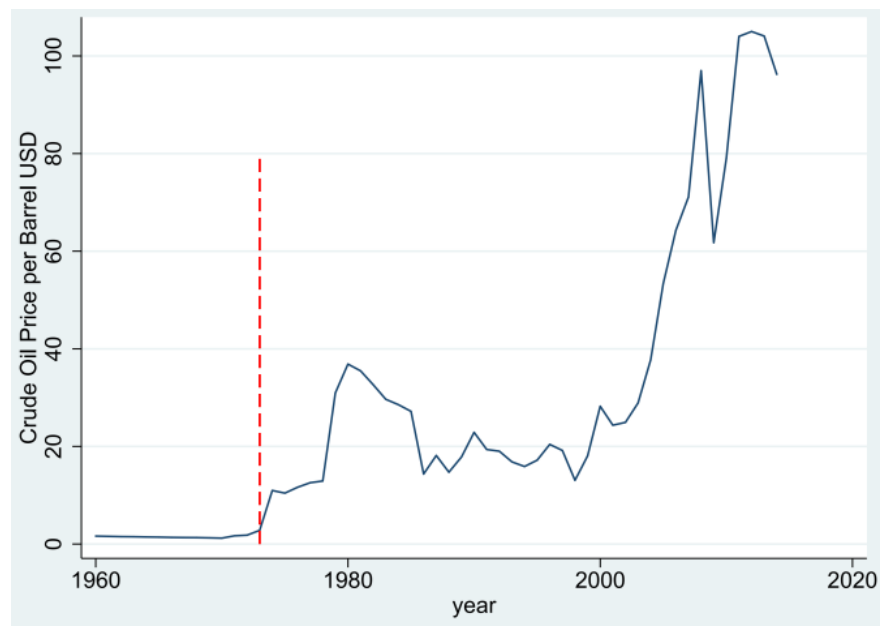

Figure 1: The global oil price trend

Another important event that must be considered is the famous "Embargo". The oil embargo began in October 1973 when Arab Nations decided to decrease their oil exports to nations they believed to be supporters of Israel. Some of targeted countries include Canada, Japan, the Netherlands, the United Kingdom, the United States, and Portugal. When the oil embargo started in October 1973, the price of oil was less than 3.0 U.S. dollars, but when it ended in March 1974 the price was 13.0 U.S. dollars. Because the oil embargo and price shock of 1973-1974

${ }^{5}$ Seven Sisters is a term for an oligopoly consisted of seven transnational oil companies of the "Consortium for Iran". The seven sisters include: 1. Anglo-Iranian (started as Anglo-Persian Oil Company. Now British Petroleum). 2. Standard Oil Company of California (Now Chevron). 3. Gulf Oil (later part of Chevron). 4. Royal Dutch Shell. 5. Standard Oil Company of New Jersey (Esso, later Exxon, now part of ExxonMobil). 6. Standard Oil Company of New York (Socony, later Mobil, now part of ExxonMobil). 7. Texaco 
coincided many believed that oil embargo caused the price increase, but as discussed above in fact Shah of Iran was behind the price increase. The western media constantly blamed the Shah for the price increase of 19731974.

After 1973 the oil income of the oil producing nations significantly increased. Figure 2.A shows daily oil revenue of the oil producing nations (i.e. the treated countries) in million U.S. dollars. As the figure shows, the real increase in oil income started in January 1974 and among Middle Eastern and North African countries, Saudi Arabia and Iran earned the highest oil incomes after the price increase. Figure 2.B represents daily oil income per capita of the treated countries in U.S dollars. As with daily oil income, daily oil income per head drastically increased after 1973. Qatar, Kuwait, and United Arab Emirates that have smaller populations earned the highest levels of oil revenue per head. The most striking feature of Figure 2.A and 2.B is the large increase in the oil income of the treated countries after 1973.

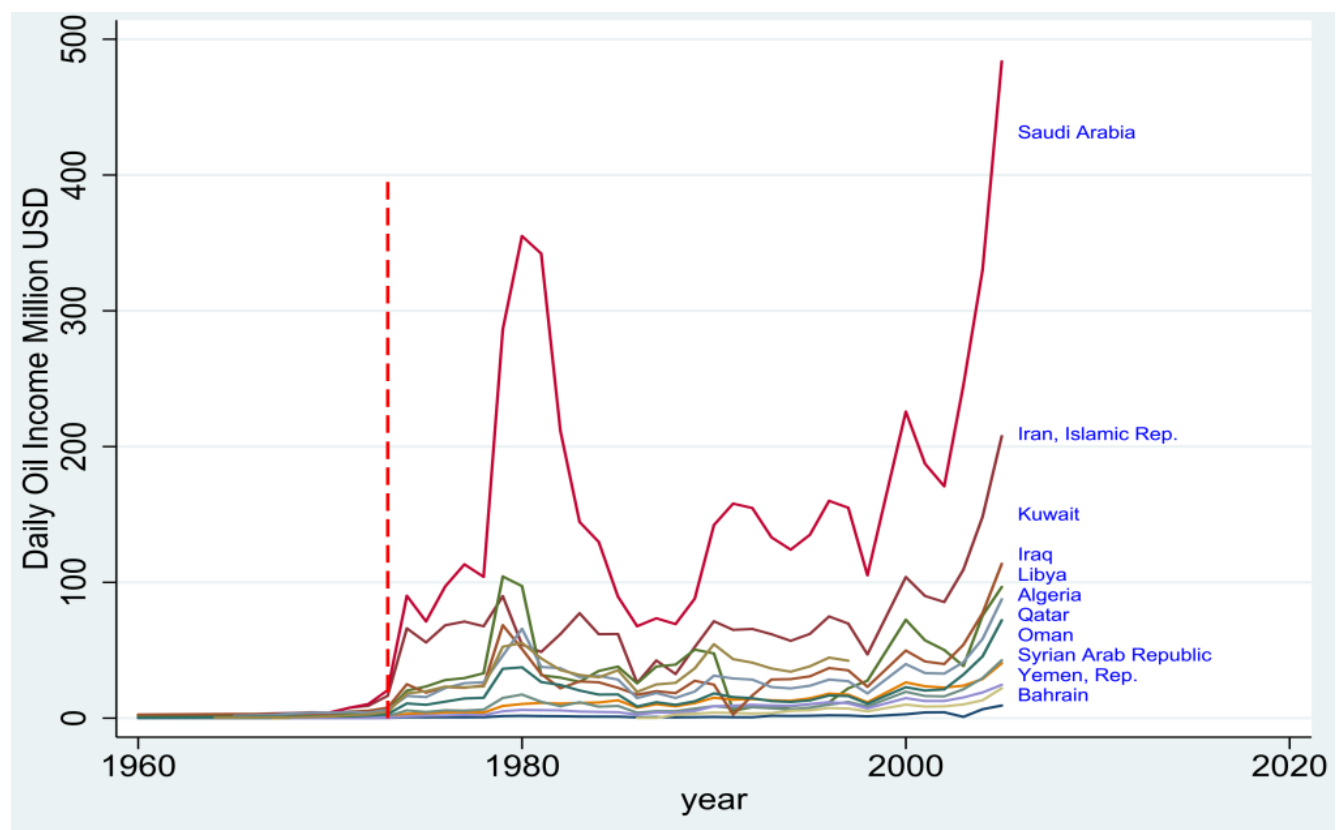

A.

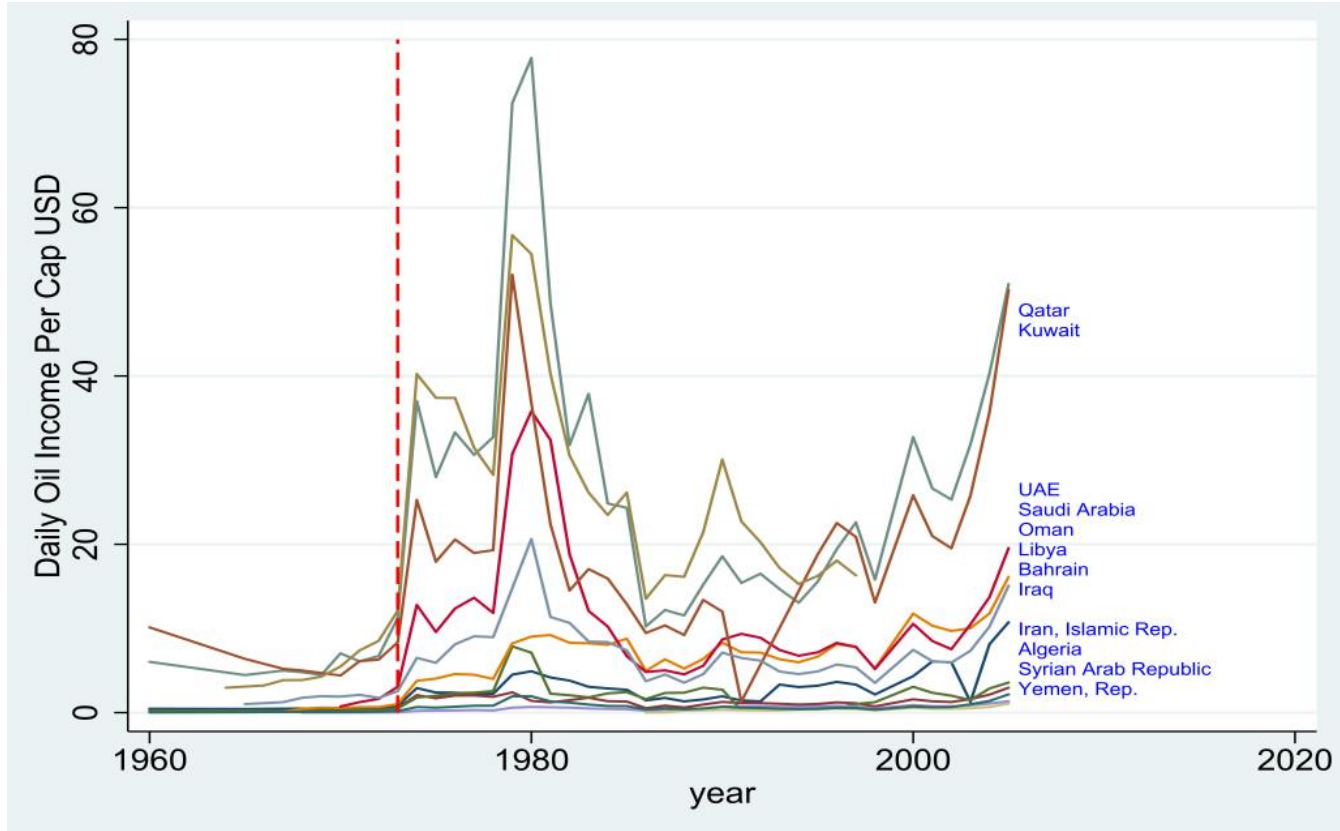

B.

Figure 2: A. Daily oil income of the treated countries in million U.S. dollars. B. Daily oil income per capita in the treated countries in U.S dollars. 


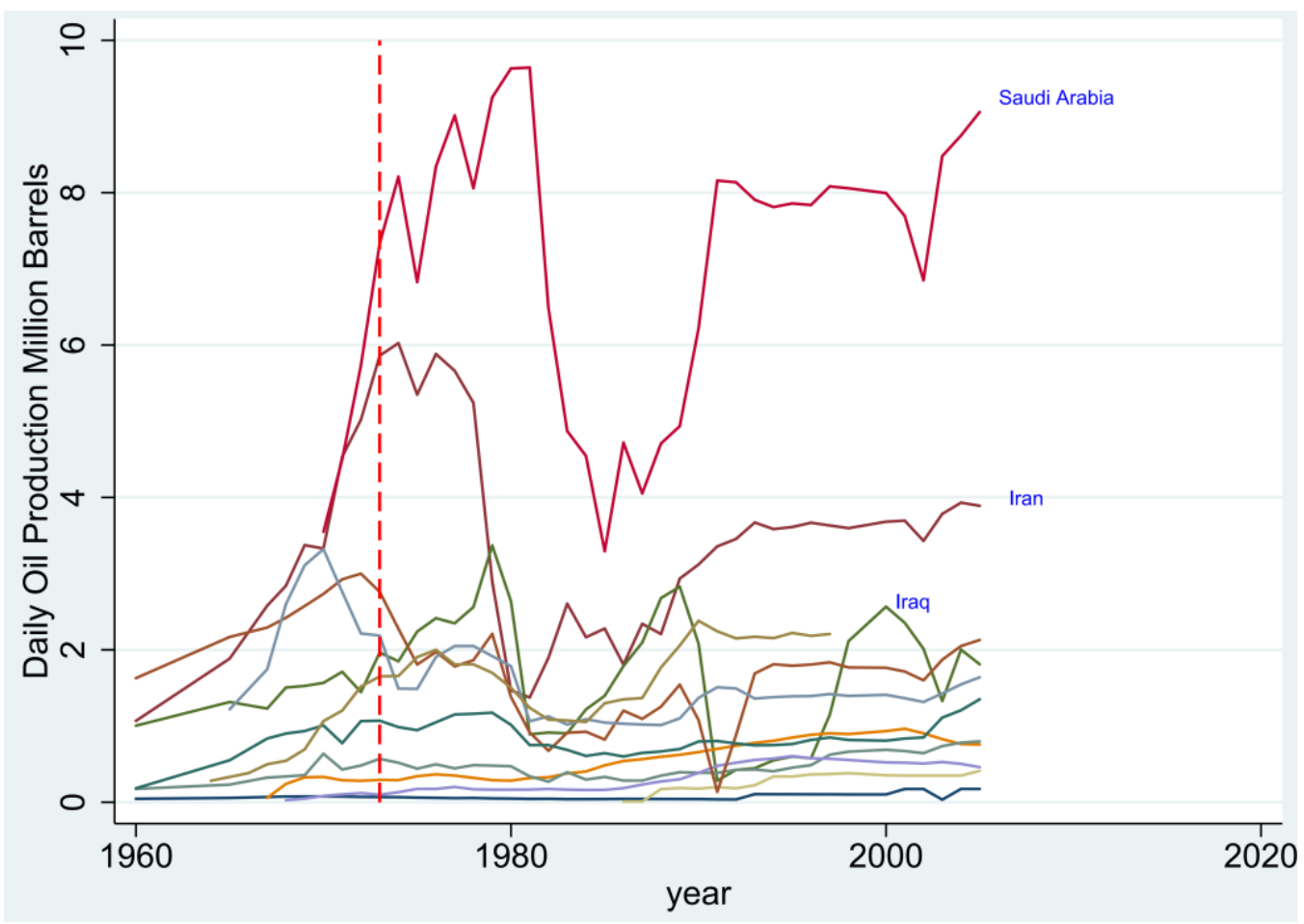

Figure 3: Daily oil production of the treated countries- million barrels

Figure 3 shows the oil production level of the treated countries in million barrels. Saudi Arabia and Iran that significantly increased their production level in the early 1970s, kept increasing it until 1975. In 1975 they both decreased their production levels to some extent which is much less than their increase in production from 1970 until 1975. Usually, the rest of the countries have been producing less oil than Saudi Arabia and Iran.

The summary statistics of the main variables of the study are represented in Table 1 In each cell three numbers are provided. The first number on top is the mean of each variable over the research period which is from 1960 to 2005. The second number in each cell which is provided in parentheses is the standard deviation and third number in the brackets represents the number of years which the mean and standard deviation of each variable are calculated for. For example, the mean of infant mortality for Algeria over the period of this research which is 55 years (from 1960 to 2014) had 76.552 per 1,000 live births with a standard deviation of 50.828. Even though for most of the variables the data is complete (i.e. the data is available for all 55 years of the study) for some of the variables we have some missing values. That is the reason why the number of observations for some variables is less than 55 .

We use four common measures of mortality rates: the infant mortality rate, the mortality rate under age five, the adult female mortality rate, and the adult male mortality rate. The reason for using four measures of mortality is that the effects of oil revenues may differ differently across age groups.

The infant mortality rate is the number of deaths of children under age one per 1,000 live births. The mortality rate for under age five is deaths of children under age five per 1,000 live births. The World Bank defines the female (male) adult mortality rates as the probability that those females (males) who have reached age 15 die before reaching age 60 . The rates are per 1,000 females (males).

Figure 4 displays the mortality rates used in this paper. Summary statistics are provided in Table 1 Figure 4 is very helpful in understanding the impacts of conflicts that affected mortality rates in the Middle East and North Africa. The most devastating war of the region was an eight-year war between Iran and Iraq from 1980 until 1988. The number of the Iranians killed in the war was very high. According to the data from the World Bank, over 500 thousand people died from both sides combined, most of whom were young males. The numbers do not 
show a considerable increase in mortality rate of females or children for any of the countries during the war. Another war was the Iraq War from March 2003 until December 2011. As can be seen from the graph, this war also contributed to an increase in mortality rate of adult males. Yet, a third conflict in the Middle East and North Africa began in 2011 which is famous as Arab Spring. In 2011 demonstrations began in Arab countries followed by changes in the political systems of some countries. In countries such as Syria the Arab Spring followed by ongoing conflicts that significantly increased mortality rates.

Note that as the table shows mortality rates were usually lowest in countries with small populations, and high GDP and oil revenues per head. Another interesting point is that mortality rates of the treated countries and the control countries are not too different. However, the average of GDP per capita in the treated nations is much higher than that of the control units.

Table 1: Summary statistics

\begin{tabular}{|c|c|c|c|c|c|c|c|c|}
\hline & $\begin{array}{c}\text { Infant } \\
\text { mortality }^{\mathrm{a}}\end{array}$ & $\begin{array}{c}\text { Mortality } \\
\text { under age } 5^{\text {b }}\end{array}$ & $\begin{array}{c}\text { Adult } \\
\text { mortality } \\
\text { female }^{c}\end{array}$ & $\begin{array}{c}\text { Adult } \\
\text { mortality } \\
\text { male }^{\mathrm{d}}\end{array}$ & $\begin{array}{l}\text { GDP per } \\
\text { capita }^{\mathrm{e}}\end{array}$ & $\begin{array}{c}\text { Daily oil } \\
\text { income per } \\
\text { head }^{\mathrm{f}}\end{array}$ & $\begin{array}{c}\text { Oil } \\
\text { production }^{\mathrm{g}}\end{array}$ & $\begin{array}{c}\text { Population } \\
\text { (millions) }\end{array}$ \\
\hline Algeria & $\begin{array}{c}76.552 \\
(50.828) \\
{[55]}\end{array}$ & $\begin{array}{c}114.7 \\
(90.357) \\
{[55]}\end{array}$ & $\begin{array}{c}191.815 \\
(80.312) \\
{[55]}\end{array}$ & $\begin{array}{c}239.147 \\
(82.567) \\
{[55]}\end{array}$ & $\begin{array}{c}2731.918 \\
(564.704) \\
{[51]}\end{array}$ & $\begin{array}{c}0.656 \\
(0.525) \\
{[39]}\end{array}$ & $\begin{array}{c}848.543 \\
(218.606) \\
{[39]}\end{array}$ & $\begin{array}{c}23.950 \\
(8.559) \\
{[55]}\end{array}$ \\
\hline Bahrain & $\begin{array}{c}33.849 \\
(32.889) \\
{[55]}\end{array}$ & $\begin{array}{c}45.109 \\
(48.897) \\
{[55]}\end{array}$ & $\begin{array}{c}116.496 \\
(47.752) \\
{[55]}\end{array}$ & $\begin{array}{c}156.541 \\
(70.607) \\
{[55]}\end{array}$ & $\begin{array}{c}4237.641 \\
(613.277) \\
{[51]}\end{array}$ & $\begin{array}{c}2.724 \\
(2.197) \\
{[40]}\end{array}$ & $\begin{array}{c}74.147 \\
(40.565) \\
{[40]}\end{array}$ & $\begin{array}{c}0.540 \\
(0.353) \\
{[55]}\end{array}$ \\
\hline Iran & $\begin{array}{c}50.584 \\
(933.024) \\
{[55]}\end{array}$ & $\begin{array}{c}68.686 \\
(50.293) \\
{[55]}\end{array}$ & $\begin{array}{c}210.315 \\
(97.752) \\
{[55]}\end{array}$ & $\begin{array}{c}287.096 \\
(123.036) \\
{[55]}\end{array}$ & $\begin{array}{c}4307.478 \\
(1178.294) \\
{[55]}\end{array}$ & $\begin{array}{c}1.149 \\
(0.706) \\
{[40]}\end{array}$ & $\begin{array}{c}3418.715 \\
(1284.591) \\
{[40]}\end{array}$ & $\begin{array}{c}49.409 \\
(18.471) \\
{[55]}\end{array}$ \\
\hline Iraq & $\begin{array}{c}56.276 \\
(27.857) \\
{[55]}\end{array}$ & $\begin{array}{c}76.325 \\
(43.366) \\
{[55]}\end{array}$ & $\begin{array}{c}201.844 \\
(80.380) \\
{[55]}\end{array}$ & $\begin{array}{c}266.796 \\
(64.062) \\
{[55]}\end{array}$ & $\begin{array}{c}2857.168 \\
(1543.254) \\
{[51]}\end{array}$ & $\begin{array}{c}1.787 \\
(1.681) \\
{[40]}\end{array}$ & $\begin{array}{c}1642.842 \\
(757.365) \\
{[40]}\end{array}$ & $\begin{array}{c}17.902 \\
(8.003) \\
{[55]}\end{array}$ \\
\hline Kuwait & $\begin{array}{c}30.516 \\
(25.798) \\
{[55]}\end{array}$ & $\begin{array}{c}39.865 \\
(37.229) \\
{[55]}\end{array}$ & $\begin{array}{c}98.092 \\
(33.836) \\
{[55]}\end{array}$ & $\begin{array}{c}144.827 \\
(41.556) \\
{[55]}\end{array}$ & $\begin{array}{c}15353.25 \\
(7460.969) \\
{[51]}\end{array}$ & $\begin{array}{c}17.281 \\
(11.740) \\
{[37]}\end{array}$ & $\begin{array}{c}1726.967 \\
(649.161) \\
{[40]}\end{array}$ & $\begin{array}{c}1.629 \\
(0.889) \\
{[52]}\end{array}$ \\
\hline Libya & $\begin{array}{c}56.372 \\
(42.293) \\
{[55]}\end{array}$ & $\begin{array}{c}79 \\
(71.735) \\
{[55]}\end{array}$ & $\begin{array}{c}176.291 \\
(75.897) \\
{[55]}\end{array}$ & $\begin{array}{c}233.701 \\
(75.734) \\
{[55]}\end{array}$ & $\begin{array}{c}4343.924 \\
(2156.769) \\
{[49]}\end{array}$ & $\begin{array}{c}6.240 \\
(3.941) \\
{[20]}\end{array}$ & $\begin{array}{c}1601.439 \\
(575.625) \\
{[38]}\end{array}$ & $\begin{array}{c}3.958 \\
(1.618) \\
{[55]}\end{array}$ \\
\hline Oman & $\begin{array}{c}66.119 \\
(63.769) \\
{[55]}\end{array}$ & $\begin{array}{c}94.334 \\
(97.212) \\
{[55]}\end{array}$ & $\begin{array}{c}185.221 \\
(93.044) \\
{[55]}\end{array}$ & $\begin{array}{c}242.024 \\
(95.162) \\
{[55]}\end{array}$ & $\begin{array}{c}5616.712 \\
(2548.245) \\
{[55]}\end{array}$ & $\begin{array}{c}6.322 \\
(3.686) \\
{[38]}\end{array}$ & $\begin{array}{c}543.918 \\
(256.252) \\
{[38]}\end{array}$ & $\begin{array}{c}1.693 \\
(0.923) \\
{[55]}\end{array}$ \\
\hline Qatar & $\begin{array}{c}20.841 \\
(13.347) \\
{[55]}\end{array}$ & $\begin{array}{c}25.543 \\
(17.582) \\
{[55]}\end{array}$ & $\begin{array}{c}91.439 \\
(33.394) \\
{[55]}\end{array}$ & $\begin{array}{c}124.339 \\
(40.571) \\
{[55]}\end{array}$ & $\begin{array}{c}19353.93 \\
(11838.27) \\
{[51]}\end{array}$ & $\begin{array}{c}23.599 \\
(17.242) \\
{[40]}\end{array}$ & $\begin{array}{c}460.317 \\
(153.209) \\
{[40]}\end{array}$ & $\begin{array}{c}0.546 \\
(0.566) \\
{[55]}\end{array}$ \\
\hline $\begin{array}{l}\text { Saudi } \\
\text { Arabia }\end{array}$ & $\begin{array}{c}41.360 \\
(29.280) \\
{[43]}\end{array}$ & $\begin{array}{c}55.141 \\
(43.577) \\
{[43]}\end{array}$ & $\begin{array}{c}168.055 \\
(82.075) \\
{[55]}\end{array}$ & $\begin{array}{c}213.859 \\
(101.162) \\
{[55]}\end{array}$ & $\begin{array}{c}9063.92 \\
(2414.286) \\
{[51]}\end{array}$ & $\begin{array}{c}10.675 \\
(8.152) \\
{[35]}\end{array}$ & $\begin{array}{c}7045.714 \\
(1836.274) \\
{[35]}\end{array}$ & $\begin{array}{c}15.062 \\
(8.433) \\
{[55]}\end{array}$ \\
\hline Syria & $\begin{array}{c}44.949 \\
(31.214) \\
{[55]}\end{array}$ & $\begin{array}{c}60.5 \\
(46.846) \\
{[55]}\end{array}$ & $\begin{array}{c}168.436 \\
(77.840) \\
{[55]}\end{array}$ & $\begin{array}{c}212.238 \\
(51.255) \\
{[55]}\end{array}$ & $\begin{array}{c}5776.062 \\
(1530.089) \\
{[50]}\end{array}$ & $\begin{array}{c}0.502 \\
(0.323) \\
{[37]}\end{array}$ & $\begin{array}{c}306.440 \\
(191.489) \\
{[37]}\end{array}$ & $\begin{array}{c}11.928 \\
(5.206) \\
{[55]}\end{array}$ \\
\hline UAE & $\begin{array}{c}36.545 \\
(38.057) \\
{[55]}\end{array}$ & $\begin{array}{c}49.738 \\
(56.705) \\
{[55]}\end{array}$ & $\begin{array}{c}134.962 \\
(58.079) \\
{[55]}\end{array}$ & $\begin{array}{c}172.802 \\
(72.505) \\
{[55]}\end{array}$ & $\begin{array}{c}19053.39 \\
(6015.65) \\
{[51]}\end{array}$ & $\begin{array}{c}21.450 \\
(14.186) \\
{[33]}\end{array}$ & $\begin{array}{c}1522.091 \\
(598.432) \\
{[33]}\end{array}$ & $\begin{array}{c}2.453 \\
(2.672) \\
{[55]}\end{array}$ \\
\hline Yemen & $\begin{array}{c}121.278 \\
(72.707) \\
{[52]}\end{array}$ & $\begin{array}{c}176.111 \\
(110.899) \\
{[52]}\end{array}$ & $\begin{array}{c}295.395 \\
(83.139) \\
{[55]}\end{array}$ & $\begin{array}{c}349.081 \\
(88.685) \\
{[55]}\end{array}$ & $\begin{array}{c}2178.319 \\
(692.059) \\
{[55]}\end{array}$ & $\begin{array}{c}.391 \\
(0.232) \\
{[19]}\end{array}$ & $\begin{array}{c}269.452 \\
(122.244) \\
{[19]}\end{array}$ & $\begin{array}{c}12.648 \\
(16.643) \\
{[55]}\end{array}$ \\
\hline $\begin{array}{l}\text { All } \\
\text { countries }\end{array}$ & $\begin{array}{c}54.080 \\
(46.257) \\
{[975]}\end{array}$ & $\begin{array}{c}74.889 \\
(71.470) \\
{[975]}\end{array}$ & $\begin{array}{c}172.203 \\
(90.181) \\
{[1,020]}\end{array}$ & $\begin{array}{c}222.974 \\
(97.474) \\
{[1,020]}\end{array}$ & $\begin{array}{c}6648.051 \\
(6653.095) \\
{[999]}\end{array}$ & $\begin{array}{c}7.845 \\
(11.329) \\
{[436]}\end{array}$ & $\begin{array}{c}1641.967 \\
(1983.831) \\
{[439]}\end{array}$ & $\begin{array}{c}12.414 \\
(16.441) \\
{[1,024]}\end{array}$ \\
\hline $\begin{array}{l}\text { Treated } \\
\text { countries }\end{array}$ & $\begin{array}{c}53.273 \\
(48.723) \\
{[622]}\end{array}$ & $\begin{array}{c}74.308 \\
(75.729) \\
{[622]}\end{array}$ & $\begin{array}{c}169.863 \\
(90.383) \\
{[660]}\end{array}$ & $\begin{array}{c}220.204 \\
(99.813) \\
{[660]}\end{array}$ & $\begin{array}{c}7869.167 \\
(7612.76) \\
{[617]}\end{array}$ & $\begin{array}{c}7.845 \\
(11.329) \\
{[436]}\end{array}$ & $\begin{array}{c}1641.967 \\
(1983.831) \\
{[439]}\end{array}$ & $\begin{array}{c}11.856 \\
(15.414) \\
{[675]}\end{array}$ \\
\hline $\begin{array}{l}\text { Control } \\
\text { Countries }\end{array}$ & $\begin{array}{c}55.501 \\
(41.585) \\
{[353]}\end{array}$ & $\begin{array}{c}75.914 \\
(63.362) \\
{[353]}\end{array}$ & $\begin{array}{c}176.493 \\
(89.777) \\
{[360]}\end{array}$ & $\begin{array}{c}228.052 \\
(92.954) \\
{[360]}\end{array}$ & $\begin{array}{c}4675.725 \\
(3991.258) \\
{[382]}\end{array}$ & 0 & 0 & $\begin{array}{c}13.364 \\
(18.041) \\
{[385]}\end{array}$ \\
\hline
\end{tabular}


Notes: The first number in each cell is the mean. The numbers in the parentheses represent standard deviations and the ones in the brackets are sample counts.
a. Infant mortality (per 1,000 live births)
b. Mortality under age 5 (per 1,000 live births)
c. Adult mortality-female (per 1,000 female adults)
d. Adult mortality-male (per 1,000 male adults)
e. Real GDP per capita in 2011 US dollars
f. The average of oil income of the country per head per day in nominal US dollars
g. Oil production (1000 barrels per day)
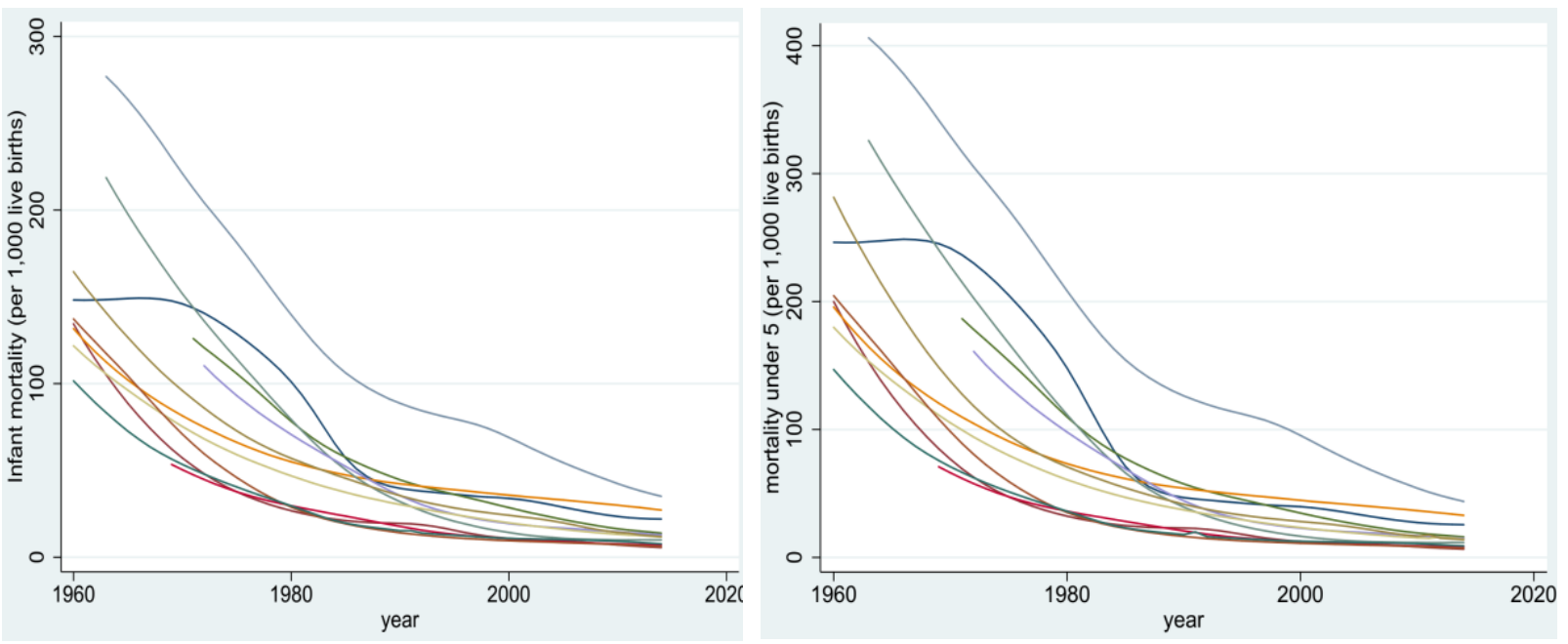

A

B
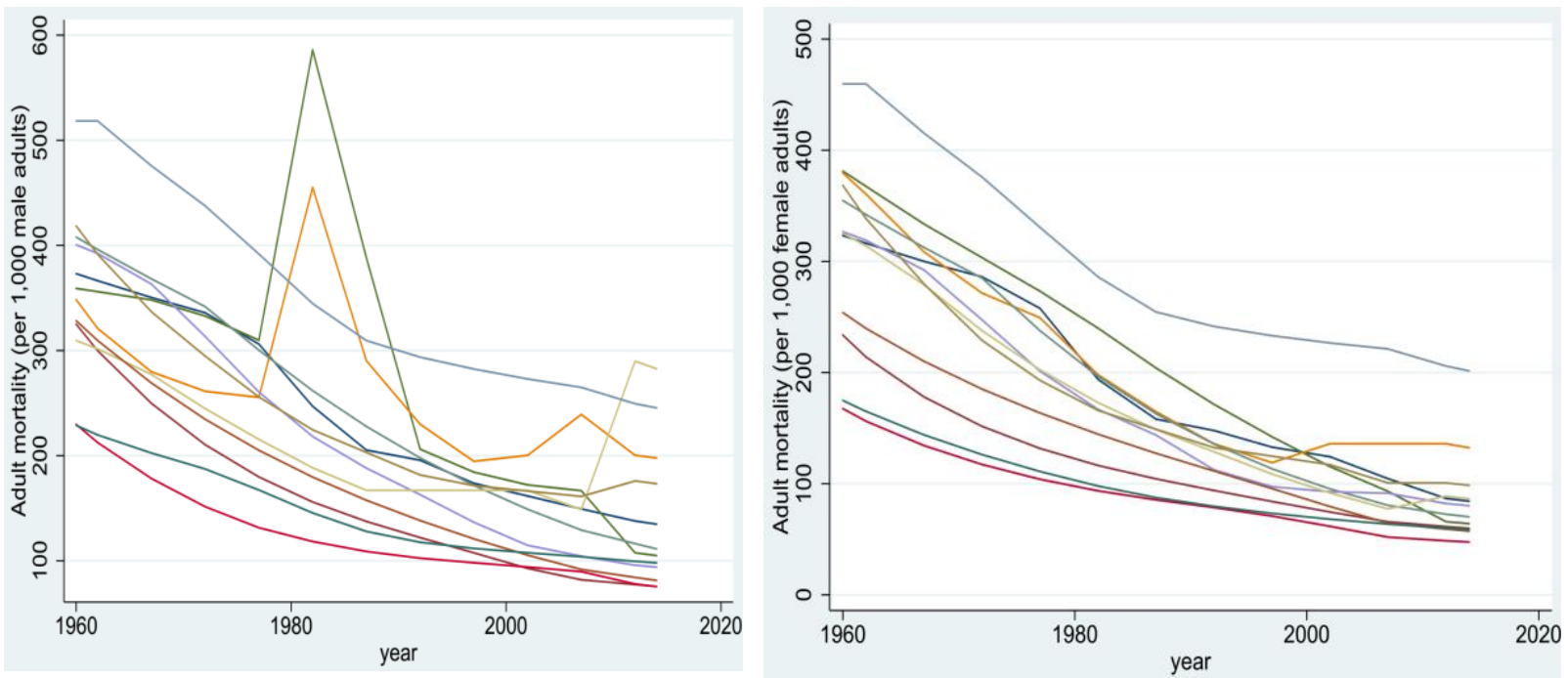

$\mathrm{D}$

Figure 4: Mortality rates: A. Infant mortality (per 1,000 live births). B. Mortality under age 5 (per 1,000 live births). C. Adult mortality-male (per 1,000 male adults). D. Adult mortality-female (per 1,000 female adults)

Table 2 reports the mean, standard deviation, and number of observations for the treated nations before 1973 and after 1973. The child mortality rate for both groups of the countries has decreased over time. However, the important point is that child mortality rate, including both infant mortality and mortality under age 5 , before the event has been more in the treated countries comparing to the control group, but it has been less after the event. The data in Table 2 does not show an improvement in mortality rates of the adults after the treatment comparing with those of the control countries. GDP per capita of the treated nations is more than that of the control group before and after the event, but the difference between the treated and control group has decreased after the event. Note the numbers in Table 2 show the average of the data for each variable over a period of time. This Table only provides some hints about the impact of the oil shock, but the impacts have been estimated and are reported in the next section. 
Table 2: Summary statistics treated versus control group before and after the event

\begin{tabular}{|c|c|c|c|c|}
\hline & \multicolumn{2}{|c|}{ 1960-1973 } & \multicolumn{2}{|c|}{$1974-2014$} \\
\hline & Treated & Control & Treated & Control \\
\hline Infant mortality rate ${ }^{\mathrm{a}}$ & $\begin{array}{c}116.257 \\
(52.895) \\
{[130]}\end{array}$ & $\begin{array}{c}106.819 \\
(39.400) \\
{[68]}\end{array}$ & $\begin{array}{c}36.631 \\
(30.652) \\
{[492]}\end{array}$ & $\begin{array}{c}43.257 \\
(31.562) \\
{[285]}\end{array}$ \\
\hline Mortality rate under age $5^{\text {b }}$ & $\begin{array}{c}173.187 \\
(84.126) \\
{[130]}\end{array}$ & $\begin{array}{c}158.770 \\
(64.904) \\
{[68]}\end{array}$ & $\begin{array}{c}48.181 \\
(46.058) \\
{[492]}\end{array}$ & $\begin{array}{c}56.145 \\
(44.116) \\
{[285]}\end{array}$ \\
\hline Adult mortality rate, female ${ }^{c}$ & $\begin{array}{c}269.812 \\
(84.426) \\
{[168]}\end{array}$ & $\begin{array}{c}272.543 \\
(70.571) \\
{[86]}\end{array}$ & $\begin{array}{c}135.735 \\
(62.887) \\
{[492]}\end{array}$ & $\begin{array}{c}146.346 \\
(72.318) \\
{[274]}\end{array}$ \\
\hline Adult mortality rate, male ${ }^{d}$ & $\begin{array}{c}312.352 \\
(81.908) \\
{[168]}\end{array}$ & $\begin{array}{c}327.391 \\
(98.374) \\
{[86]}\end{array}$ & $\begin{array}{c}188.739 \\
(84.808) \\
{[492]}\end{array}$ & $\begin{array}{c}196.873 \\
(76.305) \\
{[274]}\end{array}$ \\
\hline GDP per capita ${ }^{\mathrm{e}}$ & $\begin{array}{c}9606.389 \\
(11098.73) \\
{[168]}\end{array}$ & $\begin{array}{c}2880.831 \\
(1831.396) \\
{[97]}\end{array}$ & $\begin{array}{c}7219.159 \\
(5975.694) \\
{[492]}\end{array}$ & $\begin{array}{c}5286.618(4331.566) \\
{[285]}\end{array}$ \\
\hline Daily oil income per head ${ }^{\mathrm{f}}$ & $\begin{array}{c}2.261 \\
(2.909) \\
{[88]}\end{array}$ & 0 & $\begin{array}{c}9.257 \quad(12.202) \\
{[348]}\end{array}$ & 0 \\
\hline Oil production ${ }^{g}$ & $\begin{array}{c}1456.367 \\
(1515.359) \\
{[88]}\end{array}$ & 0 & $\begin{array}{c}1688.499 \\
(2084.1) \\
{[351]}\end{array}$ & 0 \\
\hline population (Millions) & $\begin{array}{c}5.721 \\
(7.423) \\
{[168]}\end{array}$ & $\begin{array}{c}8.293 \\
(10.898) \\
{[98]}\end{array}$ & $\begin{array}{c}13.964 \\
(16.827) \\
{[489]}\end{array}$ & $\begin{array}{c}15.096 \\
(19.619) \\
{[287]}\end{array}$ \\
\hline
\end{tabular}

Notes: The first number in each cell is the mean. The numbers in the parentheses represent standard deviations and the ones in the brackets are sample counts.

a. Infant mortality (per 1,000 live births)

b. Mortality under age 5 (per 1,000 live births)

c. Adult mortality-female (per 1,000 female adults)

d. Adult mortality-male (per 1,000 male adults)

e. Real GDP per capita in 2011 US dollars

f. The average of oil income of the country per head per day in nominal US dollars

g. Oil production (1000 barrels per day)

\section{Empirical Results}

\subsection{Difference-In-Differences}

Table 3 represents the results of difference-in-differences model (i.e. equation 1). Results for all countries in the data set are reported in column (1). In column (4) Iran and Iraq are dropped from the dataset for two reasons. The first reason goes back to the possibility of endogeneity of the treatment respect to the Iranian economy and the second reason is the Iran-Iraq war from 1980 to 1988 which increased mortality rates in both countries. In column (7), Syria and Algeria as well as Iran and Iraq are dropped from the dataset. Besides the Iran-Iraq war, another reason for dropping those countries is that they had the least oil revenue per capita in 1974 among all producing nations in the sample. By dropping them, we can see the impact of the oil price shock on the nations that income from oil has a bigger contribution to their economies. Note that even though Iran was one of the largest oil producers in the early 70s, but because it had a population of over 30 million people, its oil revenue per capita was less than most of the other oil-producing nations. In column (10), the dataset is limited to 19602010. In other words, years 2011 to 2014 are dropped. That is because of Arab Spring which affected Syria, Libya, and Yemen among the treated nations of the research and Tunisia among the countries of the control group. The two columns after columns (1), (4), (7), and (10) show the number of observations and R Squared relevant to DID estimations. All of the regressions contain country and year fixed effects. The equations are estimated with and without GDP per capita as a control variable.

As can be seen in the impacts of the 1973 oil price shock on all measures of mortality and GDP per capita are negative and statistically significant. The results show bigger impacts when GDP per capita is a control variable. 
The results in the first row and column (1) show that the impact of the oil shock on infant mortality rate is negative 17.21 which means infant mortality decreased by 17.21 per 1000 live infants every year. In addition, in the same column the impact of the oil price shock on mortality rate of children under age 5, is 25.23 fewer deaths per 1000 live births. Also, the impact of the shock on adult female and adult male mortality rates are 1.86 and 16.07 (per 1000 adults) respectively. Note that the absolute value of the impact on adult male mortality is much larger than that of the adult female mortality. The reason for this difference goes back to the Iran-Iraq war where most of the victims were adult males. The impact of the oil price shock on mortality rates of adult males is much larger when Iran and Iraq are dropped.

Also, as mentioned before, the impact of the oil shock on log of GDP per capita is negative and statistically and economically significant. This result confirms the findings of the resource curse literature.

Table 3: Difference-in-differences results

\begin{tabular}{|c|c|c|c|c|c|c|c|c|c|c|c|c|c|}
\hline & (1) & (2) & (3) & (4) & (5) & (6) & (7) & (8) & (9) & $(10)$ & (11) & (12) & (13) \\
\hline $\begin{array}{l}\text { Dependent } \\
\text { variable }\end{array}$ & $\begin{array}{c}\text { All } \\
\text { countries }\end{array}$ & $\mathrm{N}$ & $\mathrm{R} 2$ & $\begin{array}{c}\text { All countries } \\
\text { except Iran } \\
\text { and Iraq }\end{array}$ & $\mathrm{N}$ & $\mathrm{R} 2$ & $\begin{array}{c}\text { No Syria, } \\
\text { Algeria, } \\
\text { Iraq, Iran }\end{array}$ & $\mathrm{N}$ & $\mathrm{R} 2$ & $\begin{array}{c}\text { Arab Spring } \\
\& \text { no Iran } \\
\text { and Iraq }\end{array}$ & $\mathrm{N}$ & $\mathrm{R} 2$ & $\begin{array}{c}\text { Control } \\
\text { variable: } \\
\text { GDP PC }\end{array}$ \\
\hline Infant mortality ${ }^{\mathrm{a}}$ & $\begin{array}{c}-17.218^{* * *} \\
(2.823)\end{array}$ & 975 & 0.884 & $\begin{array}{c}-20.156^{* * *} \\
(2.963)\end{array}$ & 876 & 0.886 & $\begin{array}{l}-23.067 \\
(3.208)\end{array}$ & 766 & 0.884 & $\begin{array}{c}-23.697^{* * *} \\
(3.201)\end{array}$ & 706 & 0.890 & \\
\hline $\begin{array}{l}\text { Mortality under } \\
\text { age } 5^{\text {b }}\end{array}$ & $\begin{array}{c}-25.232^{* * *} \\
(4.631)\end{array}$ & 975 & 0.869 & $\begin{array}{c}-29.920^{* * * *} \\
(4.876)\end{array}$ & 876 & 0.871 & $\begin{array}{c}-31.199^{* * *} \\
(5.175)\end{array}$ & 766 & 0.870 & $\begin{array}{c}-32.119^{* * *} \\
(5.172)\end{array}$ & 706 & 0.878 & \\
\hline $\begin{array}{l}\text { Adult mortality } \\
\text { male }^{\mathrm{c}}\end{array}$ & $\begin{array}{l}-1.860^{* * *} \\
(5.719)\end{array}$ & 1,020 & 0.864 & $\begin{array}{c}-15.205^{* * *} \\
(4.373)\end{array}$ & 910 & 0.922 & $\begin{array}{c}-19.560^{* * *} \\
(4.236)\end{array}$ & 800 & 0.938 & $\begin{array}{c}-21.220^{* * *} \\
(4.244)\end{array}$ & 744 & 0.939 & \\
\hline $\begin{array}{l}\text { Adult mortality } \\
\text { female }^{\mathrm{d}}\end{array}$ & $\begin{array}{c}-16.075^{* * *} \\
(3.890)\end{array}$ & 1,020 & 0.926 & $\begin{array}{c}-10.087^{* * *} \\
(3.979)\end{array}$ & 910 & 0.927 & $\begin{array}{l}-4.808 \\
(4.328)\end{array}$ & 800 & 0.924 & $\begin{array}{c}-6.038^{* * * *} \\
(4.403)\end{array}$ & 744 & 0.923 & \\
\hline Infant mortality ${ }^{\mathrm{a}}$ & $\begin{array}{c}-25.987^{* * *} \\
(2.767)\end{array}$ & 929 & 0.898 & $\begin{array}{c}-29.467^{* * *} \\
(2.893)\end{array}$ & 838 & 0.901 & $\begin{array}{c}-36.977^{* * *} \\
(3.105)\end{array}$ & 737 & 0.905 & $\begin{array}{c}-36.207^{* * *} \\
(3.055)\end{array}$ & 701 & 0.911 & $\mathrm{Y}$ \\
\hline $\begin{array}{l}\text { Mortality under } \\
\text { age } 5^{\text {b }}\end{array}$ & $\begin{array}{c}-40.065^{* * *} \\
(4.502)\end{array}$ & 929 & 0.887 & $\begin{array}{c}-46.058^{* * *} \\
(4.716)\end{array}$ & 838 & 0.891 & $\begin{array}{c}-54.080^{* * *} \\
(4.981)\end{array}$ & 737 & 0.895 & $\begin{array}{c}-52.801^{* * *} \\
(4.901)\end{array}$ & 701 & 0.902 & $\mathrm{Y}$ \\
\hline $\begin{array}{l}\text { Adult mortality } \\
\text { male }^{c}\end{array}$ & $\begin{array}{l}-13.193^{* * *} \\
(5.502)\end{array}$ & 974 & 0.882 & $\begin{array}{c}-30.953^{* * *} \\
(3.747)\end{array}$ & 872 & 0.947 & $\begin{array}{c}-39.024^{* * *} \\
(3.923)\end{array}$ & 771 & 0.952 & $\begin{array}{c}-38.332^{* * *} \\
(3.966)\end{array}$ & 739 & 0.952 & $\mathrm{Y}$ \\
\hline $\begin{array}{l}\text { Adult mortality } \\
\text { female }^{\mathrm{d}}\end{array}$ & $\begin{array}{c}-30.302^{* * *} \\
(3.487)\end{array}$ & 974 & 0.945 & $\begin{array}{c}-26.050^{* * * *} \\
(3.620)\end{array}$ & 872 & 0.944 & $\begin{array}{l}-24.717 \\
(4.053)\end{array}$ & 771 & 0.941 & $\begin{array}{l}-23.885^{* * *} \\
(4.105)\end{array}$ & 739 & 0.940 & $\mathrm{Y}$ \\
\hline $\log$ GDP $p c^{\mathrm{e}}$ & $\begin{array}{l}-0.349^{* * *} \\
(0.054)\end{array}$ & 999 & 0.808 & $\begin{array}{l}-0.324^{\text {*** }} \\
(0.055)\end{array}$ & 897 & 0.826 & $\begin{array}{l}-0.425^{* * *} \\
(0.059)\end{array}$ & 796 & 0.827 & $\begin{array}{l}-0.429^{\text {*** }} \\
(0.060)\end{array}$ & 760 & 0.825 & \\
\hline
\end{tabular}

Notes: All regressions include country and region-year fixed effects. The numbers in parentheses represent standard errors.

a. Infant mortality (per 1,000 live births)

b. Mortality under age 5 (per 1,000 live births)

c. Adult mortality-male (per 1,000 male adults)

d. Adult mortality-female (per 1,000 female adults)

e. Logarithm of real GDP per capita in 2011 US dollars

* Significant at $10 \%$

** Significant at 5\%

*** Significant at $1 \%$

\subsection{Robustness Check}

One concern is that because of the increase in price of oil in 1979 the parallel trend assumption might not hold. Therefore, the analysis is repeated using observations for 1960-1978. The impacts of the 1973 oil price shock on mortality rates that are reported in Table 4 are, to a high extent, similar to the results in Table 3 Even though the size of the dataset is smaller in Table 4 (only five years) the coefficients are not too different from those of the complete dataset in Table 3.

However, in Table 4 the coefficient of Log of GDP per capita is not statistically significant. Perhaps, the reason is that resource curse (the negative impacts of natural resource revenues on economic growth) does not happen as fast as five years after an increase in oil revenues. Note that the reason that Israel has been dropped in the 
second series of the estimation in Table 4 is that that Israel has a more advanced economy as compared to the countries in the treated group or the ones of control group. Dropping Israel has a very marginal impact on the size of the coefficients without any impact on their signs.

Table 4: Robustness check; difference-in-differences estimations. 1960-1978

\begin{tabular}{|c|c|c|c|c|c|c|c|c|c|c|}
\hline $\begin{array}{l}\text { Dependent } \\
\text { variable }\end{array}$ & $\begin{array}{c}\text { All } \\
\text { countries }\end{array}$ & $\mathrm{N}$ & $\mathrm{R} 2$ & $\begin{array}{c}\text { All } \\
\text { countries } \\
\text { except } \\
\text { Israel }\end{array}$ & & & $\begin{array}{l}\text { All countries } \\
\text { except Iran }\end{array}$ & $\mathrm{N}$ & $\mathrm{R} 2$ & $\begin{array}{c}\text { Control } \\
\text { variable: } \\
\text { GDP PC }\end{array}$ \\
\hline Infant mortality ${ }^{\mathrm{a}}$ & $\begin{array}{c}-15.457^{* * * *} \\
(4.245)\end{array}$ & 291 & 0.957 & $\begin{array}{c}-15.457^{\text {**** }} \\
(3.108)\end{array}$ & 286 & 0.955 & $\begin{array}{c}-15.437^{* * *} \\
(3.150)\end{array}$ & 283 & 0.957 & \\
\hline $\begin{array}{l}\text { Mortality under } \\
\text { age } 5^{\text {b }}\end{array}$ & $\begin{array}{c}-23.696^{* * * *} \\
(4.849)\end{array}$ & 291 & 0.958 & $\begin{array}{c}-23.696^{* * *} \\
(4.883)\end{array}$ & 286 & 0.957 & $\begin{array}{c}-23.637^{* * *} \\
(4.950)\end{array}$ & 283 & 0.958 & \\
\hline $\begin{array}{l}\text { Adult mortality } \\
\text { male }^{c}\end{array}$ & $\begin{array}{l}-0.564 \\
(4.235)\end{array}$ & 344 & 0.961 & $\begin{array}{l}-0.564 \\
(4.178)\end{array}$ & 342 & 0.962 & $\begin{array}{l}-3.840 \\
(4.101)\end{array}$ & 325 & 0.966 & \\
\hline $\begin{array}{l}\text { Adult mortality } \\
\text { female }^{\mathrm{d}}\end{array}$ & $\begin{array}{l}-6.520^{*} \\
(3.584)\end{array}$ & 344 & 0.973 & $\begin{array}{l}-6.520^{*} \\
(3.550)\end{array}$ & 342 & 0.973 & $\begin{array}{l}-6.541^{*} \\
(3.749)\end{array}$ & 325 & 0.972 & \\
\hline Infant mortality ${ }^{\mathrm{a}}$ & $\begin{array}{c}-16.546^{* * *} \\
(3.024)\end{array}$ & 290 & 0.959 & $\begin{array}{c}-16.548^{* * *} \\
(3.050)\end{array}$ & 285 & 0.957 & $\begin{array}{c}-16.664^{* * *} \\
(3.095)\end{array}$ & 282 & 0.959 & $\mathrm{Y}$ \\
\hline $\begin{array}{l}\text { Mortality under } \\
\text { age } 5^{\text {b }}\end{array}$ & $\begin{array}{c}-25.719^{* * *} \\
(4.687)\end{array}$ & 290 & 0.962 & $\begin{array}{c}-25.724^{* * *} \\
(4.719)\end{array}$ & 285 & 0.960 & $\begin{array}{c}-25.926^{* * *} \\
(4.789)\end{array}$ & 282 & 0.962 & $\mathrm{Y}$ \\
\hline $\begin{array}{l}\text { Adult mortality } \\
\text { male }^{\mathrm{c}}\end{array}$ & $\begin{array}{l}-0.361 \\
(4.205)\end{array}$ & 343 & 0.962 & $\begin{array}{l}-0.322 \\
(4.141)\end{array}$ & 341 & 0.963 & $\begin{array}{l}-3.845 \\
(4.033)\end{array}$ & 324 & 0.968 & $\mathrm{Y}$ \\
\hline $\begin{array}{l}\text { Adult mortality } \\
\text { female }^{d}\end{array}$ & $\begin{array}{l}-6.198^{*} \\
(3.520)\end{array}$ & 343 & 0.974 & $\begin{array}{l}-6.169^{*} \\
(3.479)\end{array}$ & 341 & 0.974 & $\begin{array}{l}-6.490^{*} \\
(3.680)\end{array}$ & 324 & 0.973 & Y \\
\hline Log GDP $p c^{h}$ & $\begin{array}{c}0.062 \\
(0.054)\end{array}$ & 360 & 0.957 & $\begin{array}{c}0.086 \\
(0.056)\end{array}$ & 341 & 0.956 & $\begin{array}{c}0.036 \\
(0.053)\end{array}$ & 341 & 0.958 & \\
\hline
\end{tabular}

Notes: All regressions include country and region-year fixed effects. The number in parenthesis represent standard errors.

a. Infant mortality (per 1,000 live births)

b. Mortality under age 5 (per 1,000 live births)

c. Adult mortality-male (per 1,000 male adults)

d. Adult mortality-female (per 1,000 female adults)

e. Logarithm of real GDP per capita in 2011 US dollars

* Significant at $10 \%$

** Significant at $5 \%$

*** Significant at $1 \%$

Because the price of oil started to increase in 1970, 1970 might be the year that should be considered as the event year. Hence, the results reported in Table 5 use the event year of 1970. As can be observed, the results are similar to the ones in Table 3 In most cases, the impacts of the oil shock on child and adult mortality rates is negative and statistically significant. Again, the impact of the oil shock on per capita GDP is negative and statistically significant. However, the impact on income is smaller when the event year is 1970 rather than 1973.

Table 5: Robustness Check; difference-in-differences estimations. Event year 1970

\begin{tabular}{|c|c|c|c|c|c|c|c|c|c|c|c|c|c|}
\hline $\begin{array}{l}\text { Dependent } \\
\text { variable }\end{array}$ & $\begin{array}{c}\text { All } \\
\text { countries }\end{array}$ & $\mathrm{N}$ & $\mathrm{R} 2$ & $\begin{array}{c}\text { All } \\
\text { countries } \\
\text { except } \\
\text { Israel }\end{array}$ & $\mathrm{N}$ & $\mathrm{R} 2$ & $\begin{array}{c}\text { All } \\
\text { countries } \\
\text { except Iran } \\
\text { and Iraq }\end{array}$ & $\mathrm{N}$ & $\mathrm{R} 2$ & $\begin{array}{c}\text { Arab } \\
\text { Spring }\end{array}$ & $\mathrm{N}$ & $\mathrm{R} 2$ & $\begin{array}{c}\text { Control } \\
\text { variable: } \\
\text { GDP PC }\end{array}$ \\
\hline Infant mortality ${ }^{\mathrm{a}}$ & $\begin{array}{c}-19.303^{* * *} \\
(3.123)\end{array}$ & 975 & 0.884 & $\begin{array}{c}-19.303^{\text {**** }} \\
(3.137)\end{array}$ & 934 & 0.883 & $\begin{array}{c}-22.790^{* * * *} \\
(3.268)\end{array}$ & 876 & 0.887 & $\begin{array}{c}-23.232^{* * * *} \\
(2.261)\end{array}$ & 808 & 0.892 & \\
\hline $\begin{array}{l}\text { Mortality under } \\
\text { age } 5^{\text {b }}\end{array}$ & $\begin{array}{c}-28.798^{* * * *} \\
(5.120)\end{array}$ & 975 & 0.869 & $\begin{array}{c}-28.798^{* * * *} \\
(5.147)\end{array}$ & 934 & 0.869 & $\begin{array}{c}-34.445^{\text {*** }} \\
(5.375)\end{array}$ & 876 & 0.872 & $\begin{array}{c}-35.083^{* * *} \\
(5.372)\end{array}$ & 808 & 0.878 & \\
\hline $\begin{array}{l}\text { Adult mortality } \\
\text { male }^{\mathrm{c}}\end{array}$ & $\begin{array}{l}-2.050 \\
(6.217)\end{array}$ & 1,020 & 0.864 & $\begin{array}{c}1.243 \\
(6.320)\end{array}$ & 990 & 0.861 & $\begin{array}{c}-15.268^{* * * *} \\
(4.760)\end{array}$ & 910 & 0.922 & $\begin{array}{c}-17.906^{* * *} \\
(4.385)\end{array}$ & 846 & 0.934 & \\
\hline $\begin{array}{l}\text { Adult mortality } \\
\text { female }^{\mathrm{d}}\end{array}$ & $\begin{array}{c}-16.229^{* * * *} \\
(4.234)\end{array}$ & 1,020 & 0.926 & $\begin{array}{c}-13.404^{* * *} \\
(4.282)\end{array}$ & 990 & 0.925 & $\begin{array}{c}-10.286^{* * *} \\
(4.328)\end{array}$ & 910 & 0.927 & $\begin{array}{c}-11.095^{* * * *} \\
(4.382)\end{array}$ & 846 & 0.926 & \\
\hline Infant mortality ${ }^{\mathrm{a}}$ & $-26.373^{* * * *}$ & 929 & 0.896 & $-27.674^{* * *}$ & 888 & 0.901 & $-30.116^{* * *}$ & 838 & 0.900 & $-29.309^{* * * *}$ & 802 & 0.905 & Y \\
\hline
\end{tabular}




\begin{tabular}{|c|c|c|c|c|c|c|c|c|c|c|c|c|c|}
\hline & $(3.042)$ & & & $(2.973)$ & & & $(3.169)$ & & & $(3.121)$ & & & \\
\hline $\begin{array}{l}\text { Mortality under } \\
\text { age } 5^{\text {b }}\end{array}$ & $\begin{array}{c}-40.707^{* * *} \\
(4.945)\end{array}$ & 929 & 0.886 & $\begin{array}{c}-42.804^{* * *} \\
(4.831)\end{array}$ & 888 & 0.892 & $\begin{array}{c}-46.866^{* * *} \\
(5.161)\end{array}$ & 838 & 0.889 & $\begin{array}{c}-45.578^{* * *} \\
(5.089)\end{array}$ & 802 & 0.895 & $\mathrm{Y}$ \\
\hline $\begin{array}{l}\text { Adult mortality } \\
\text { male }^{c}\end{array}$ & $\begin{array}{r}-11.373 \\
(5.911)\end{array}$ & 974 & 0.882 & $\begin{array}{l}-8.054 \\
(5.959)\end{array}$ & 944 & 0.881 & $\begin{array}{c}-27.960^{* * * *} \\
(4.060)\end{array}$ & 872 & 0.946 & $\begin{array}{c}-27.267^{* * * *} \\
(4.089)\end{array}$ & 840 & 0.946 & Y \\
\hline $\begin{array}{l}\text { Adult mortality } \\
\text { female }^{\mathrm{d}}\end{array}$ & $\begin{array}{c}-27.446^{* * *} \\
(3.787)\end{array}$ & 974 & 0.943 & $\begin{array}{c}-24.254^{* * *} \\
(3.728)\end{array}$ & 944 & 0.945 & $\begin{array}{l}-22.995^{* * *} \\
(3.915)\end{array}$ & 872 & 0.943 & $\begin{array}{c}-22.305^{* * *} \\
(3.946)\end{array}$ & 840 & 0.943 & $\mathrm{Y}$ \\
\hline Log GDP $p c^{h}$ & $\begin{array}{l}-0.285^{* * * *} \\
(0.059)\end{array}$ & 999 & 0.805 & $\begin{array}{l}-0.231^{* * * *} \\
(0.063)\end{array}$ & 944 & 0.792 & $\begin{array}{l}-0.262^{* * * *} \\
(0.060)\end{array}$ & 897 & 0.822 & $\begin{array}{l}-0.264^{\text {**** }} \\
(0.061)\end{array}$ & 861 & 0.820 & \\
\hline
\end{tabular}

Notes: All regressions include country and region-year fixed effects. The number in parenthesis represent standard errors.

a. Infant mortality (per 1,000 live births)

b. Mortality under age 5 (per 1,000 live births)

c. Adult mortality-female (per 1,000 female adults)

d. Adult mortality-male (per 1,000 male adults)

e. Logarithm of real GDP per capita in 2011 US dollars

* Significant at $10 \%$

** Significant at $5 \%$

*** Significant at $1 \%$

\subsection{Impact on Hospital Beds}

The findings of this paper to this point are highly puzzling. Our results show that the oil shock in 1973 had a negative impact on GDP per capita, but improved mortality rates (i.e. decreased mortality). In this section we try to identify the plausible channel through which the windfall revenue from the oil decreased mortality ${ }^{6}$. Here we have estimated the impacts of the oil shock in 1973 on the number of hospital beds per head. Figure 5 that is provided in Appendix A shows the number of hospital beds per head in each country over the period of the research (i.e. 1960-2014).

As the table shows, the effect of the oil price shock on the number of hospital beds is positive and economically and statistically significant. Assuming that means that the health sector has been growing after the oil shock, then Dutch Disease hypothesis can provide us with a plausible channel that the oil shock could have improved the mortality rate despite its negative impact on economic growth.

One prediction of Dutch Disease is that if the oil sector employs a low ratio of workers of the whole economy (which in practice is the case in any economy), then the spending effect (i.e. increase in aggregate demand in the services sector because of the oil price shock) dominates the resource movement effect (i.e. movement of labor and capital from agriculture and manufacturing sectors to the oil sector because of the oil price shock) which leads to an increase in output and employment in services sector (such as health sector) ${ }^{7}$.

Table 6: difference-in-differences estimations: impacts of oil shock on hospital beds

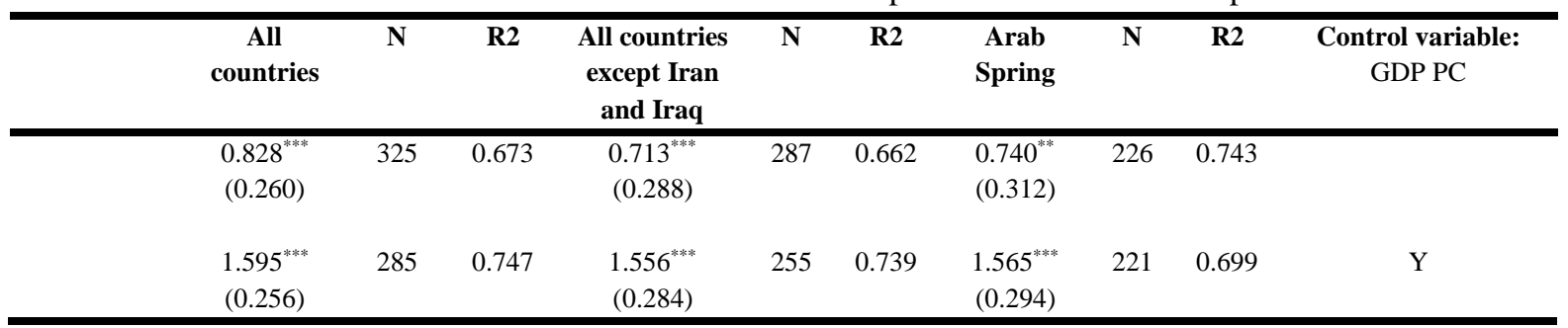

Dependent variable: Number of hospital beds per person. All regressions include country and region-year fixed effects. The number in parenthesis represent standard errors.

* Significant at $10 \%$

** Significant at 5\%

*** Significant at $1 \%$

\footnotetext{
${ }^{6}$ Note that other factors such as improvement in water and sanitations might take place after the windfall revenues take place. That also could affect mortality.

${ }^{7}$ see the introduction for more details
} 


\subsection{Event studies}

$\mathrm{n}$ this section we provide the event study estimations. Instead of the interactions of event and post in equation 1 we have used interactions of event and three-year dummy variables. This specification allows the treatment effect to vary over time. The three-year dummy variable that indicates 1971 to 1973 period (i.e. equals to one if year is 1971, 1972, or 1973 and equals to zero otherwise) has been omitted from the regression. The reason is that identification in this specification comes from comparing the outcome variables to the omitted 3-years period prior the event. Also, the associated estimations are provided in Table 7 As can be seen in the figure and the table, the coefficients are not significant prior to the oil shock in 1973. However, after a few years the significant coefficients appear. As the results show the impacts of the oil shock on mortality rates and economic growth are negative.

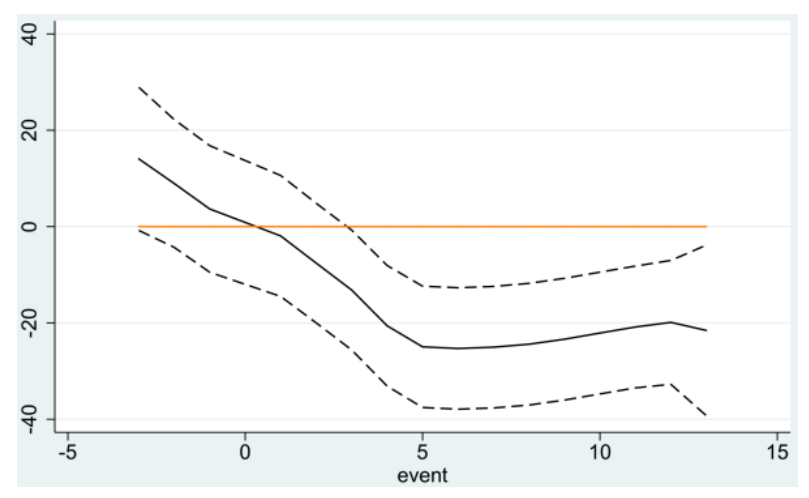

A.

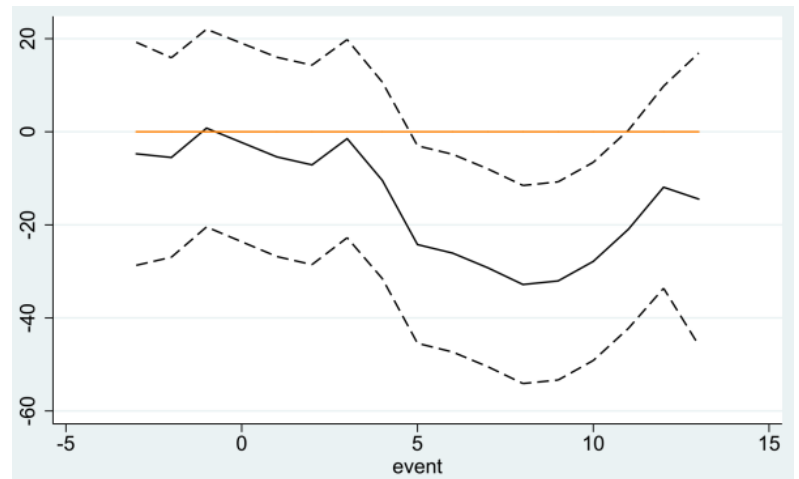

C.

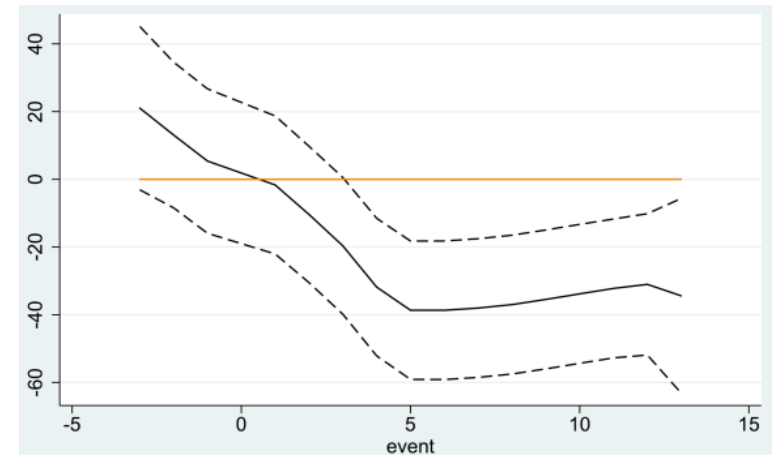

B.

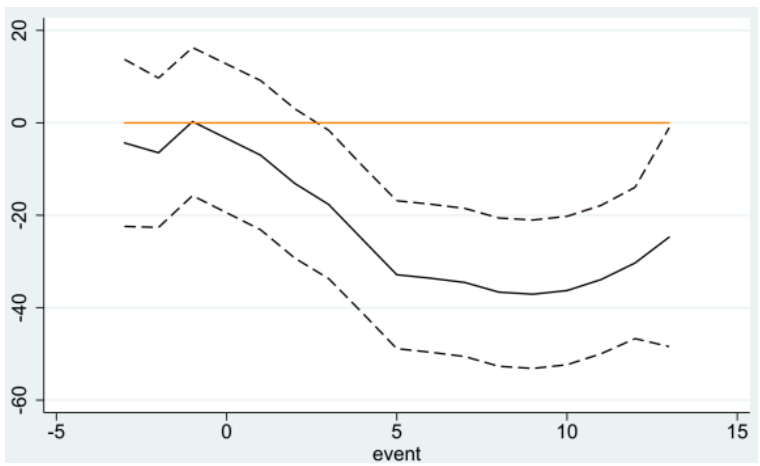

D.

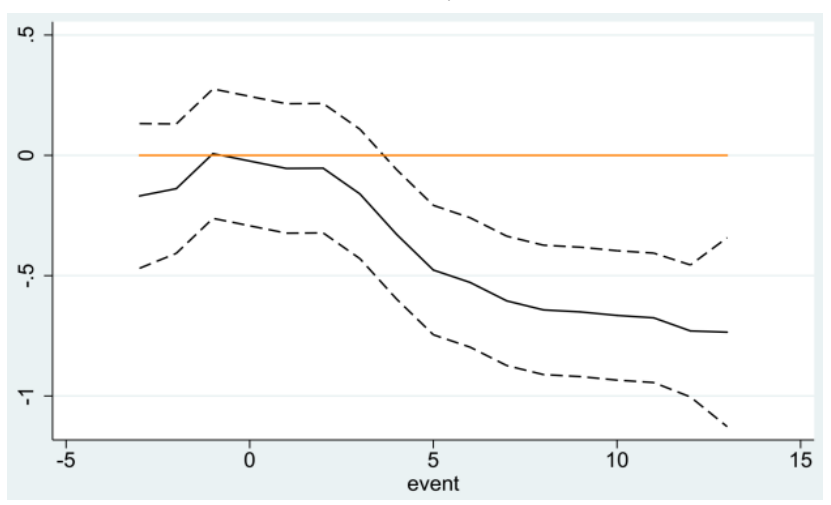

E.

Figure 6: Event studies. A. Infant mortality, B. Mortality under age 5, C. Adult mortality male, D. Adult mortality female, E. GDP per capit

Notes: All regressions include country and region-year fixed effects. the numbers on horizontal axes show the associated event (see Table 7). The numbers on the vertical axes show the size of the coefficient (i.e. interaction of the event and 3-years dummy variables). Event is a dummy variable that equals to one if a country is one of the treated countries and it is equal to zero if the country is 
Table 7: Event study estimations

\begin{tabular}{|c|c|c|c|c|c|c|}
\hline Event & Event year & Infant mortality & $\begin{array}{c}\text { Mortality under } \\
\text { age } 5\end{array}$ & $\begin{array}{c}\text { Adult male } \\
\text { mortality }\end{array}$ & $\begin{array}{c}\text { Adult female } \\
\text { mortality }\end{array}$ & Log GDP pc \\
\hline-3 & $1962-1964$ & $\begin{array}{l}14.065^{*} \\
(7.566)\end{array}$ & $\begin{array}{c}21.02^{*} \\
(12.281)\end{array}$ & $\begin{array}{c}-4.735 \\
(12.209)\end{array}$ & $\begin{array}{l}-4.343 \\
(9.205)\end{array}$ & $\begin{array}{l}-0.168 \\
(0.153)\end{array}$ \\
\hline-2 & $1965-1967$ & $\begin{array}{r}8.942 \\
(6.752)\end{array}$ & $\begin{array}{c}13.075 \\
(10.960)\end{array}$ & $\begin{array}{c}-5.524 \\
(10.917)\end{array}$ & $\begin{array}{l}-6.478 \\
(8.231)\end{array}$ & $\begin{array}{l}-0.138 \\
(0.137)\end{array}$ \\
\hline-1 & 1968-1970 & $\begin{array}{r}3.665 \\
(6.694)\end{array}$ & $\begin{array}{c}5.386 \\
(10.856)\end{array}$ & $\begin{array}{c}0.784 \\
(10.820)\end{array}$ & $\begin{array}{c}0.265 \\
(8.158)\end{array}$ & $\begin{array}{r}0.007 \\
(0.137)\end{array}$ \\
\hline 0 & $1971-1973$ & -- & -- & -- & -- & -- \\
\hline 1 & 1974-1976 & $\begin{array}{l}-1.936 \\
(6.752)\end{array}$ & $\begin{array}{c}-1.661 \\
(10.382)\end{array}$ & $\begin{array}{c}-5.399 \\
(10.909)\end{array}$ & $\begin{array}{l}-7.001 \\
(8.225)\end{array}$ & $\begin{array}{l}-0.054 \\
(0.137)\end{array}$ \\
\hline 2 & $1977-1979$ & $\begin{array}{l}-7.566 \\
(6.322)\end{array}$ & $\begin{array}{l}-10.375 \\
(10.262)\end{array}$ & $\begin{array}{c}-7.111 \\
(10.916)\end{array}$ & $\begin{array}{l}-13.094 \\
(8.231)\end{array}$ & $\begin{array}{l}-0.053 \\
(0.137)\end{array}$ \\
\hline 3 & 1980-1982 & $\begin{array}{c}-13.158^{* * *} \\
(6.335)\end{array}$ & $\begin{array}{l}-19.656^{*} \\
(10.283)\end{array}$ & $\begin{array}{c}-1.475 \\
(10.843)\end{array}$ & $\begin{array}{c}-17.669^{* * *} \\
(8.176)\end{array}$ & $\begin{array}{l}-0.160 \\
(0.137)\end{array}$ \\
\hline 4 & 1983-1985 & $\begin{array}{c}-20.586^{* * *} \\
(6.375)\end{array}$ & $\begin{array}{l}-31.834^{* * *} \\
(10.347)\end{array}$ & $\begin{array}{l}-10.446 \\
(10.753)\end{array}$ & $\begin{array}{c}-25.290^{* * * *} \\
(8.108)\end{array}$ & $\begin{array}{l}-0.328^{* *} \\
(0.137)\end{array}$ \\
\hline 5 & 1986-1988 & $\begin{array}{c}-24.958^{* * * *} \\
(6.415)\end{array}$ & $\begin{array}{l}-38.668^{* * * *} \\
(10.412)\end{array}$ & $\begin{array}{l}-24.244^{* *} \\
(10.811)\end{array}$ & $\begin{array}{c}-32.864^{* * * *} \\
(8.151)\end{array}$ & $\begin{array}{c}-0.476^{* * * *} \\
(0.137)\end{array}$ \\
\hline 6 & $1989-1991$ & $\begin{array}{c}-25.301^{* * *} \\
(6.421)\end{array}$ & $\begin{array}{c}-38.678^{* * *} \\
(10.422)\end{array}$ & $\begin{array}{l}-26.082^{* *} \\
(10.820)\end{array}$ & $\begin{array}{c}-33.621^{* * * *} \\
(8.158)\end{array}$ & $\begin{array}{l}-0.528^{* * * *} \\
(0.137)\end{array}$ \\
\hline 7 & 1992-1994 & $\begin{array}{c}-25.029^{* * *} \\
(6.426)\end{array}$ & $\begin{array}{c}-38.025^{\text {*** }} \\
(10.430)\end{array}$ & $\begin{array}{c}-29.231^{\text {*** }} \\
(10.827)\end{array}$ & $\begin{array}{c}-34.548^{* * *} \\
(8.163)\end{array}$ & $\begin{array}{c}-0.604^{* * * *} \\
(0.137)\end{array}$ \\
\hline 8 & 1995-1997 & $\begin{array}{c}-24.414^{* * *} \\
(6.433)\end{array}$ & $\begin{array}{c}-37.004^{* * *} \\
(10.442)\end{array}$ & $\begin{array}{c}-32.825^{\text {***k }} \\
(10.838)\end{array}$ & $\begin{array}{c}-36.639^{* * * *} \\
(8.172)\end{array}$ & $\begin{array}{c}-0.642^{* * * *} \\
(0.137)\end{array}$ \\
\hline 9 & $1998-2000$ & $\begin{array}{c}-23.373^{* * *} \\
(6.438)\end{array}$ & $\begin{array}{l}-35.473 \\
(10.450)\end{array}$ & $\begin{array}{c}-32.055^{* * * *} \\
(10.845)\end{array}$ & $\begin{array}{c}-37.075^{* * *} \\
(8.177)\end{array}$ & $\begin{array}{c}-0.650^{* * *} \\
(0.137)\end{array}$ \\
\hline 10 & $2001-2003$ & $\begin{array}{c}-22.098^{* * * *} \\
(6.439)\end{array}$ & $\begin{array}{c}-33.827^{\text {*** }} \\
(10.451)\end{array}$ & $\begin{array}{l}-27.860^{* *} \\
(10.847)\end{array}$ & $\begin{array}{c}-36.284^{* * * *} \\
(8.178)\end{array}$ & $\begin{array}{c}-0.665^{* * *} \\
(0.137)\end{array}$ \\
\hline 11 & 2004-2006 & $\begin{array}{c}-20.837^{\text {*** }} \\
(6.437)\end{array}$ & $\begin{array}{c}-32.232^{\text {*** }} \\
(10.449)\end{array}$ & $\begin{array}{l}-20.946^{*} \\
(10.844)\end{array}$ & $\begin{array}{c}-33.908^{* * *} \\
(8.176)\end{array}$ & $\begin{array}{c}-0.675^{* * * *} \\
(0.137)\end{array}$ \\
\hline 12 & 2007-2009 & $\begin{array}{c}-19.879^{* * *} \\
(6.549)\end{array}$ & $\begin{array}{c}-31.029^{* * * *} \\
(10.630)\end{array}$ & $\begin{array}{l}-11.914 \\
(10.061)\end{array}$ & $\begin{array}{c}-30.315^{* * * *} \\
(8.340)\end{array}$ & $\begin{array}{c}-0.729^{\text {***k }} \\
(0.137)\end{array}$ \\
\hline 13 & 2010-2012 & $\begin{array}{l}-21.545^{\text {** }} \\
(9.018)\end{array}$ & $\begin{array}{c}-34.409^{* *} \\
(10.638)\end{array}$ & $\begin{array}{l}-14.474 \\
(10.996)\end{array}$ & $\begin{array}{l}-24.730^{\text {*** }} \\
(12.061)\end{array}$ & $\begin{array}{c}-0.735^{\text {**** }} \\
(0.200)\end{array}$ \\
\hline
\end{tabular}

All regressions include country and region-year fixed effects. The number in parenthesis represent standard errors. The interaction of event and the dummy variable that indicate years 1971 to 1973 is omitted.

* Significant at $10 \%$

** Significant at 5\%

*** Significant at $1 \%$

\subsection{Obtaining stationary residuals}

Table 8 presents unit root tests results. The reason behind providing this table is that the sample in this paper includes fifty-five time periods and if the residuals of the regressions are not stationary then the findings might not be consistent. So, we do Fisher-type unit-root test on the residuals of the difference-in-differences regressions from the estimates of equation 1. Fisher-type unit-root test is based on Augmented Dickey-Fuller test methodology.

The null hypothesis here is that "All panels contain unit roots" and the alternative hypothesis is "At least one panel is stationary". As can be seen in Table 8, for all of the estimations the null hypothesis is rejected at $1 \%$ significance level. In other words, we do not see any evidence that the residualscontain unit roots. Therefore, the findings of the difference-in-differences regressions should be consistent 
Table 8: Fisher-type unit-root test based on Augmented Dickey-Fuller test

\begin{tabular}{lc}
\hline Dependent variable & All co \\
\hline Infant mortality & 232.884 \\
Mortality under age 5 & 245.85 \\
Adult mortality male & 85.014 \\
Adult mortality female & 127.839 \\
Log GDP pc & 99.490 \\
\hline Notes: The H0 and Ha hypotheses of Augmented Dick \\
Ho: All panels contain unit roots \\
Ha: At least one panel is stationary \\
\\
$* * *:$ reject the null hypothesis at $1 \%$ significance level \\
$* *:$ reject the null hypothesis at 5\% significance level \\
$*:$ reject the null hypothesis at 10\% significance level
\end{tabular}

\section{Conclusion}

The focus of this research is on studying the impacts of the oil price shock of December 1973 on the mortality rates of the oil producer nations. We have argued in the paper that the oil price shock in 1973 is an exogenous variable if not for the Iranian economy, but the rest of the world. We use longitudinal data from 1960 to 2014 and we apply difference-in-differences (DID) methodology to investigate our research questions. Our data covers the Middle East and North Africa region.

Key findings of this research can be summarized as follow:

The oil price increase of 1973 reduced mortality rates in the oil-producing nations of the Middle East and North Africa. The findings hold for all measures of mortality: infant mortality rate, mortality rate under age 5, and adult male and female mortality rates. Besides, the results show a negative impact of the oil price shock of 1973 on per capita GDP.

These findings are puzzling. Therefore, we have tried to find the plausible channel through which the oil price shock in 1973 has improved the health sector. We estimated the impact of the oil price shock on the number of hospital beds and we found a positive and statistically and economically significant impact on the number of hospital beds.

The results can be explained by the Dutch Disease hypothesis. According to the predictions of the Dutch Disease hypothesis if the oil sector hires a relatively low percentage of the population, then a boom in oil prices weakens the manufacturing and agriculture sectors and strengthens the services sector. Since the services sector includes the health sector and we have found negative impacts of the oil price shock on GDP per capita, (this could imply that the effect of the shock on manufacturing and agriculture has been negative $\left.{ }^{8}\right)$ the Dutch Disease's prediction might apply to the findings of our study.

The findings indicate that the impact of the oil price shock in 1973 on mortality rates in the Middle East and North Africa is negative but more research is needed to investigate the same research question applying to other contexts. Also, we do not know with confidence whether the findings of this research apply to the other oilproducing nations.

\section{Acknowledgments}

I sincerely thank Andrew Mason, Sang-Hyop Lee, Inessa Love, Timothy Halliday, Teresa Molina, Nori Tarui, Michael Roberts, Sumner J. La Croix, Ekaterina Sherstyuk, John Lynham, and Josephine Ofori Adofo for their valuable inputs and comments. I bear sole responsibility for the content of this research and all errors remain mine.

${ }^{8}$ GDP includes data from all sectors including, oil, manufacturing, agriculture, and services. A decline in GDP is not necessarily because of decline in production of agriculture and manufacturing. 


\section{References}

Acemoglu, D., Finkelstein, A., \& Notowidigdo, M. J. (2013). Income and health spending: Evidence from oil price shocks. Review of Economics and Statistics, 95(4), 1079-1095.

Aydin, L., \& Acar, M. (2011). Economic impact of oil price shocks on the Turkish economy in the coming decades: A dynamic CGE analysis. Energy Policy, 39(3), 1722-1731.

Becker, G. S., Philipson, T. J., \& Soares, R. R. (2005). The quantity and quality of life and the evolution of world inequality. The American Economic Review, 95(1), 277-291.

Bergmann, P. (2019). Oil price shocks and GDP growth: Do energy shares amplify causal effects?. Energy Economics, 80, 1010-1040.

Bloom, D., \& Canning, D. (2007). Commentary: The Preston Curve 30 years on: Still sparking fires. International Journal of Epidemiology, 36(3), 498-499.

Braveman, P. A., Cubbin, C., Egerter, S., Williams, D. R., \& Pamuk, E. (2010). Socioeconomic disparities in health in the United States: what the patterns tell us. American journal of public health, 100(S1), S186S196.

Brollo, F., Nannicini, T., Perotti, R., \& Tabellini, G. (2010). The political resource curse. American Economic Review, 103(5):1759-96.

Card, D., \& Krueger, A. B. (1994). Minimum wages and employment: A case study of the fast food industry in New Jersey and Pennsylvania (No. w4509). National Bureau of Economic Research.

Caselli, F., \& Cunningham, T. (2009). Leader behaviour and the natural resource curse. Oxford Economic Papers, 61(4), 628-650.

Caselli, F., \& Michaels, G. (2009a). Resource abundance, development, and living standards: evidence from oil discoveries in Brazil. NBER Working Paper, 15550.

Caselli, F., \& Michaels, G. (2009b). Do oil windfalls improve living standards? Evidence from Brazil (No. w15550). National Bureau of Economic Research.

Chetty, R., Stepner, M., Abraham, S., Lin, S., Scuderi, B., Turner, N., ... \& Cutler, D. (2016). The association between income and life expectancy in the United States, 2001-2014. Jama, 315(16), 1750-1766.

CIA report, Shah of Iran Culprit in High Oil Prices, CIA-RDP91-00561R000100070048-2.

Cristia, J. P., DeLeire, A. H., Iams, H., Kile, J., Manchester, J., Meyerson, N., ... \& Walker, L. (2007). The empirical relationship between lifetime earnings and mortality. Congressional Budget Office.

Cross, J., \& Nguyen, B. H. (2017). The relationship between global oil price shocks and China's output: A timevarying analysis. Energy economics, 62, 79-91.

Cunado, J., \& de Gracia, F. P. (2014). Oil price shocks and stock market returns: Evidence for some European countries. Energy Economics, 42, 365-377.

Cunado, J., Jo, S., \& de Gracia, F. P. (2015). Macroeconomic impacts of oil price shocks in Asian economies. Energy Policy, 86, 867-879.

Cutler, D., Lleras-Muney, A., \& Deaton, A. (2006). The Determinants of Mortality. 20(3), 97-120.

Deaton, A. (2006). The great escape: A review of Robert Fogel's the escape from hunger and premature death, 1700-2100. Journal of Economic Literature, 44(1), 106-114.

Demeny, P. (1965). Investment Allocation and Population Growth. Demography, 2, 203-232.

Duggan, J. E., Greenlees, J. S., \& Gillingham, R. (2008). Mortality and lifetime income: evidence from US social security records (No. 7-15). International Monetary Fund.

Farzanegan, M. R., \& Markwardt, G. (2009). The effects of oil price shocks on the Iranian economy. Energy Economics, 31(1), 134-151.

Fogel, R. W. (2004). The escape from hunger and premature death, 1700-2100: Europe, America, and the Third World (Vol. 38). Cambridge University Press.

Fogel, R. W. (2004). The escape from hunger and premature death, 1700-2100: Europe, America, and the Third World (Vol. 38). Cambridge University Press.

Gao, L., Kim, H., \& Saba, R. (2014). How do oil price shocks affect consumer prices?. Energy Economics, 45, 313-323.

Grigoli, F., Herman, A., \& Swiston, A. (2019). A crude shock: Explaining the short-run impact of the 2014-16 oil price decline across exporters. Energy Economics, 78, 481-493.

Gylfason, T. (2001). Natural resources, education, and economic development. European economic review, 45(4), 847-859.

Gylfason, T., Herbertsson, T., \& Zoega, G. (1999). A MIXED BLESSING. Macroeconomic Dynamics, 3(02), 204-225.

Hasanov, F. (2013). Dutch disease and the Azerbaijan economy. Communist and Post-Communist Studies, 46(4), 463-480.

Herrera, A. M., Karaki, M. B., \& Rangaraju, S. K. (2019). Oil price shocks and US economic activity. Energy policy, 129, 89-99. 
Ioannidis, C., \& Ka, K. (2018). The impact of oil price shocks on the term structure of interest rates. Energy Economics, 72, 601-620.

Iwayemi, A., \& Fowowe, B. (2011). Impact of oil price shocks on selected macroeconomic variables in Nigeria. Energy policy, 39(2), 603-612.

Jimenez-Rodriguez, R. (2008). The impact of oil price shocks: Evidence from the industries of six OECD countries. Energy Economics, 30(6), 3095-3108.

Jo, S., Karnizova, L., \& Reza, A. (2018). Industry effects of oil price shocks: A re-examination. Energy Economics.

Ju, K., Su, B., Zhou, D., Wu, J., \& Liu, L. (2016). Macroeconomic performance of oil price shocks: Outlier evidence from nineteen major oil-related countries/regions. Energy Economics, 60, 325-332.

Kang, W., Ratti, R. A., \& Yoon, K. H. (2014). The impact of oil price shocks on US bond market returns. Energy Economics, 44, 248-258.

Kim, W. J., Hammoudeh, S., Hyun, J. S., \& Gupta, R. (2017). Oil price shocks and China's economy: Reactions of the monetary policy to oil price shocks. Energy Economics, 62, 61-69.

Kitagawa, E., \& Hauser, Philip M. (1973). Differential Mortality in the United States: A Study in Socioeconomic Epidemiology.

Lee, C. C., \& Lee, C. C. (2019). Oil price shocks and Chinese banking performance: Do country risks matter?. Energy Economics, 77, 46-53.

Lee, C. C., Lee, C. C., \& Ning, S. L. (2017). Dynamic relationship of oil price shocks and country risks. Energy Economics, 66, 571-581.

Leite, C. A., \& Weidmann, J. (1999). Does mother nature corrupt? Natural resources, corruption, and economic growth. Natural Resources, Corruption, and Economic Growth (June 1999). IMF Working Paper, (99/85).

Lorusso, M., \& Pieroni, L. (2018). Causes and consequences of oil price shocks on the UK economy. Economic Modelling, 72, 223-236.

Mackenbach, J. P., \& Looman, C. W. (2013). Life expectancy and national income in Europe, 1900-2008: an update of Preston's analysis. International journal of epidemiology, 42(4), 1100-1110.

Mackenbach, J. P., Stirbu, I., Roskam, A. J. R., Schaap, M. M., Menvielle, G., Leinsalu, M., \& Kunst, A. E. (2008). Socioeconomic inequalities in health in 22 European countries. New England Journal of Medicine, 358(23), 2468-2481.

Michaels, G. (2011). The long-term consequences of resource-based specialisation. The Economic Journal, 121(551), 31-57.

Moshiri, S., \& Moghaddam, M. B. (2018). The effects of oil price shocks in a federation; The case of interregional trade and labour migration. Energy Economics, 75, 206-221.

Nasir, M. A., Naidoo, L., Shahbaz, M., \& Amoo, N. (2018). Implications of oil prices shocks for the major emerging economies: A comparative analysis of BRICS. Energy Economics, 76, 76-88.

Nusair, S. A. (2016). The effects of oil price shocks on the economies of the Gulf Co-operation Council countries: Nonlinear analysis. Energy Policy, 91, 256-267.

Nusair, S. A., \& Olson, D. (2019). The effects of oil price shocks on Asian exchange rates: Evidence from quantile regression analysis. Energy Economics, 78, 44-63.

Oladosu, G. A., Leiby, P. N., Bowman, D. C., Uría-Martínez, R., \& Johnson, M. M. (2018). Impacts of oil price shocks on the United States economy: A meta-analysis of the oil price elasticity of GDP for net oilimporting economies. Energy policy, 115, 523-544.

Oomes, N., \& Kalcheva, K. (2007). Diagnosing Dutch disease: does Russia have the symptoms? (Vol. 7). International Monetary Fund.

Papavlassopulos, N., \& Keppler, D. (2011). Life expectancy as an objective factor of a subjective wellbeing. Social indicators research, 104(3), 475-505.

Papyrakis, E., \& Gerlagh, R. (2007). Resource abundance and economic growth in the United States. European Economic Review, 51(4), 1011-1039.

Park, J., \& Ratti, R. A. (2008). Oil price shocks and stock markets in the US and 13 European countries. Energy economics, 30(5), 2587-2608.

Preston, S. (2007). The changing relation between mortality and level of economic development. International Journal of Epidemiology, 36(3), 484-490.

Preston, S. H. (1975). The changing relation between mortality and level of economic development. Population studies, 29(2), 231-248.

Ross, M. L. (2001). Does oil hinder democracy?. World politics, 53(3), 325-361.

Sachs, J. D., \& Warner, A. M. (1995). Natural resource abundance and economic growth (No. w5398). National Bureau of Economic Research.

Sala-i-Martin, X., \& Subramanian, Arvind. (2013). Addressing the natural resource curse an illustration from Nigeria. Journal of African Economies, 22(4), 570-615.

Scholtens, B., \& Yurtsever, C. (2012). Oil price shocks and European industries. Energy Economics, 34(4), 1187-1195. 
Smith, B. (2015). The resource curse exorcised: Evidence from a panel of countries. Journal of development economics, 116, 57-73.

Stolnitz, G. (1965). Recent mortality trends in Latin America, Asia and Africa. Population Studies, 19(2), $117-$ 138.

Tchatoka, F. D., Masson, V., \& Parry, S. (2018). Linkages between oil price shocks and stock returns revisited. Energy Economics.

Tornell, A., \& Lane, P. R. (1999). The voracity effect. american economic review, 22-46.

Tsai, C. L. (2015). How do US stock returns respond differently to oil price shocks pre-crisis, within the financial crisis, and post-crisis?. Energy Economics, 50, 47-62.

Van der Ploeg, F. (2011). Natural resources: Curse or blessing?. Journal of Economic Literature, 366-420.

Velasco, A. (1997). A model of endogenous fiscal deficits and delayed fiscal reforms (No. w6336). National Bureau of Economic Research.

Vicente, P. C. (2010). Does oil corrupt? Evidence from a natural experiment in West Africa. Journal of Development Economics, 92(1), 28-38.

Waldron, H. (2013). Mortality differentials by lifetime earnings decile: Implications for evaluations of proposed social security law changes. Social Security Bulletin, 73(1), 1-37.

Zhang, C., \& Qu, X. (2015). The effect of global oil price shocks on China's agricultural commodities. Energy Economics, 51, 354-364.

Zhang, C., \& Tu, X. (2016). The effect of global oil price shocks on China's metal markets. Energy Policy, 90, 131-139.

Zhao, L., Zhang, X., Wang, S., \& Xu, S. (2016). The effects of oil price shocks on output and inflation in China. Energy Economics, 53, 101-110. 
Appendix A: Hospital beds per head in treated countries

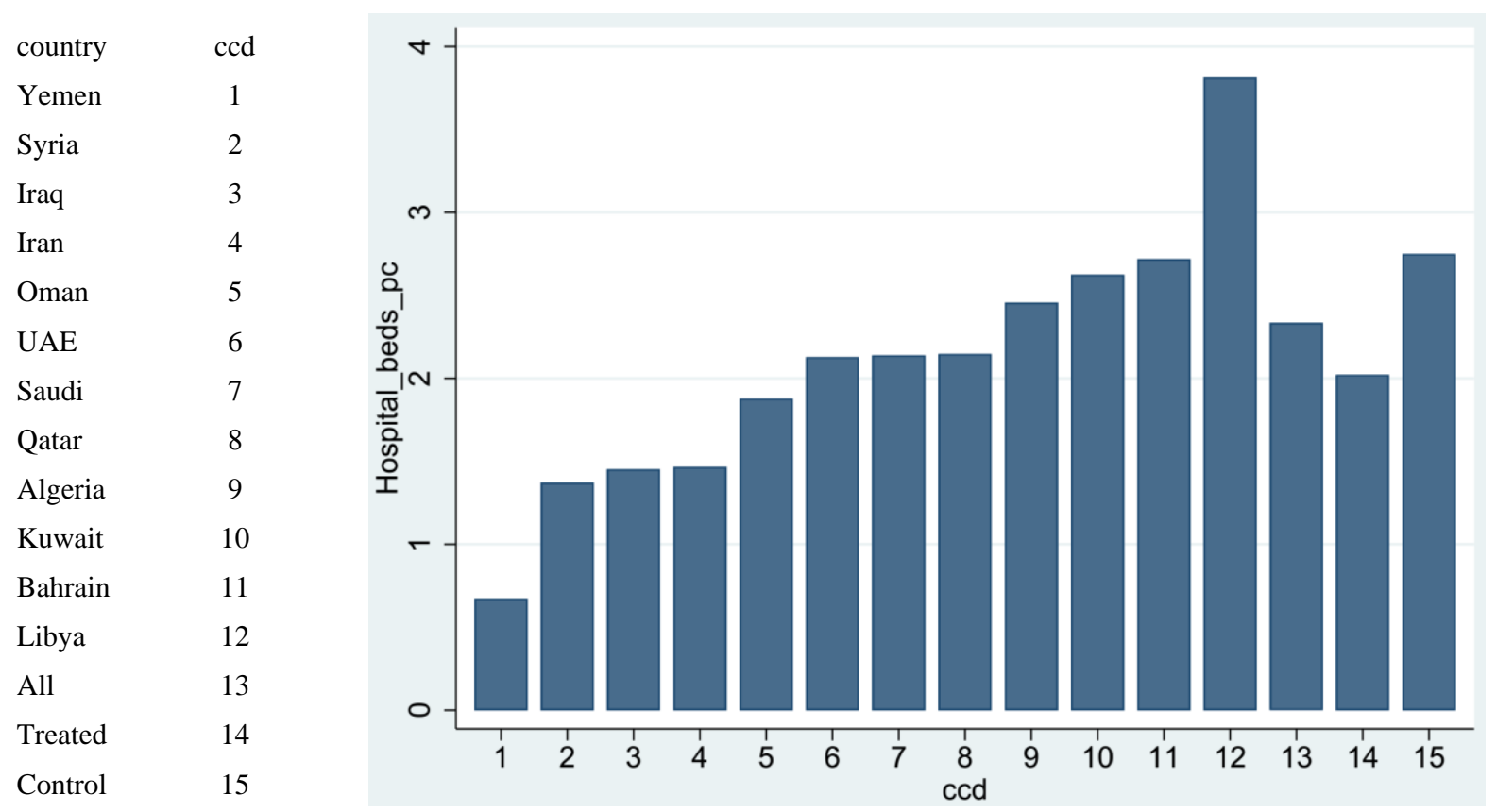

Figure 5: number of hospital beds per head in each treated country

The two columns in the left side of the figure show the country code (ccd) associated with each country. 